\title{
Migration paths of magma and fluids and lava compositions in Kamchatka
}

\author{
N.L. Dobretsov a,c, I.Yu. Koulakov a,*, Yu.D. Litasov ${ }^{\text {b,c }}$ \\ ${ }^{\mathrm{a}}$ A.A. Trofimuk Institute of Petroleum Geology and Geophysics, Siberian Branch of the Russian Academy of Sciences, \\ pr. Akademika Koptyuga 3, Novosibirsk, 630090, Russia \\ ${ }^{\mathrm{b}}$ V.S. Sobolev Institute of Geology and Mineralogy, Siberian Branch of the Russian Academy of Sciences, \\ pr. Akademika Koptyuga 3, Novosibirsk, 630090, Russia \\ ${ }^{\mathrm{c}}$ Novosibirsk State University, ul. Pirogova 2, Novosibirsk, 630090, Russia
}

Received 18 May 2012; accepted 21 June 2012

Available online xx November 2012

\begin{abstract}
Geophysical and geochemical data have been analyzed jointly in order to gain better understanding of subduction-related active volcanism in Kamchatka. The velocity structure of lithosphere beneath volcanic arcs has been imaged on three scales. Regional tomography to distances of thousands of kilometers has allowed constraints on slab geometry, which changes markedly in dip angle and thickness beneath the Kuriles-Kamchatka arc, possibly, because of a change in the interplay of the subduction driving forces. Intermediate-scale regional tomography (hundreds of kilometers) has been applied to the cases of Toba caldera in Sumatra, Mount Merapi in Java, and volcanoes in the Central Andes and provided evidence of magma conduits marked by low-velocity zones that link the suprasubduction volcanic arcs with clusters of earthquake hypocenters on the slab top. Local tomography resolves the shallow structure immediately under volcanoes and the geometry of respective melting zones. An example time-lapse (4D) seismic model of the crust beneath the Klyuchevskoy group of volcanoes has imaged a decade-long history of anomalous velocity zones and their relation with the activity cycles of Bezymyanny and Klyuchevskoy volcanoes. As modeling shows, andesitic Bezymyanny and basaltic Klyuchevskoy volcanoes have different feeding patterns during their eruption cycles: the former feeds directly from the mantle while the material coming to the latter passes through a complicated system of intermediate chambers.

The local tomography model has been applied as reference to interpret the available major- and trace-element data from the Klyuchevskoy and Bezymyanny volcanoes. The lava compositions of the two volcanoes have becoming ever more proximal since 1945 in many major and trace elements while some parameters remain different. Paroxysmal eruptions of Bezymyanny for several recent decades correlate with the time when Klyuchevskoy erupted lavas with high percentages of high-Mg basalts. The difference in the evolution trends of the Kamchatka volcanic rocks may be due either to fractional crystallization or to the presence of concentrator minerals in the source, titanomagnetite, orthopyroxene, rutile, garnet, and plagioclase being especially active as to uptake of some elements. The natural compositions of rocks have been compared in this context with published experimental data.

According to the seismic velocity structure and lava compositions analyzed jointly, there are five levels of crystallization beneath the studied volcanoes, while the number and spatial patterns of magma sources are different for two types of andesitic volcanoes.
\end{abstract}

(C) 2012, V.S. Sobolev IGM, Siberian Branch of the RAS. Published by Elsevier B.V. All rights reserved.

Keywords: seismic tomography; subduction; volcanic arcs; lava compositions; melting zone; migration of melts and fluids; Kamchatka

\section{Introduction}

Subduction-related volcanism is among most complicated geological phenomena with multiple controls from agents dispersed geographically, in depth, and in time. That is why integrated studies of geology, petrology, chemistry, and geophysics are required to gain better understanding of subsurface mechanisms that drive the evolution of volcanic systems. Combining seismic tomography with petrological and chemi-

\footnotetext{
* Corresponding author.

E-mail address: koulakoviyu@ipgg.nsc.ru (I.Yu. Koulakov)
}

cal analyses is a good tool in this respect. Tomography at different scales resolves reliably the crustal and upper mantle structure and its possible links with eruption events observed on the surface. Petrology and chemistry, in turn, can reveal imprints of deep processes in the compositions of rocks and minerals.

In this study we are trying to profit as far as possible from the advantages of both methods to study volcanism in the Kuriles-Kamchatka subduction zone, with implications for the migration paths and interaction of suprasubdution fluids and melts.

The views of subduction volcanism have been changed a lot through the past ten or fifteen years. The sketch of Fig. 1 
represents a subduction zone as it was modeled in the late 1980s, with five segments of the slab upper part and three zones of volcanism above them: a fore-arc with boninites (I); a principal (frontal) arc (II), and a back arc (III). There are an accretionary prism (1) and a dehydration zone (2) before the fronts of arcs I and II, a zone of phase transition to garnet amphibolite and eclogite and initial melting below (3), a still deeper zone of bulk melting of oceanic crust producing andesitic melts (4), and a melting zone at the back (or underneath, in a mantle wedge) that produces tholeiitic alkali basalts (5). The predicted temperature pattern records the melting temperature at the slab top (till 1000-1200 ${ }^{\circ} \mathrm{C}$ ) and a hot suprasubduction zone $\left(\leq 1400{ }^{\circ} \mathrm{C}\right)$ where the rising melts and fluids react with the ambient mantle.

In Figure 2 this simplified model is applied to Kamchatka and shows depthward arc projections to the slab surface: $100-140 \mathrm{~km}$ for the frontal arc and as deep as 170-200 km or even more than $300 \mathrm{~km}$ at the back. Each belt involves groups of volcanoes spaced at about $100 \mathrm{~km}$. The same pattern is common to other modern arcs, as well as to paleo-arcs. Grouping of volcanoes was attributed to the formation of multiple separate hot flows (plumes) rising through the mantle wedge, which was first predicted in (Dobretsov and Kirdyashkin, 1997) and then substantiated by seismic tomography and numerical modeling (Tamura et al., 2002). Some typical groups of volcanoes are discussed below.

That model received much criticism in the 1990s as new evidence of the temperature pattern became available which placed the melting temperatures $1000-1200{ }^{\circ} \mathrm{C}$ at $200 \mathrm{~km}$ and deeper. A large (or greater) part of arcs are basaltic rather than andesitic, with partition coefficients of many geochemical tracers corresponding to primitive basalt instead of andesite. That new knowledge gave rise to the idea that fluids (rather than andesitic melts) would rise from subducting slabs and react with hotter ambient mantle to form high-Al or high-Mg basaltic melts. The latter would experience fractional crystallization in intermediate chambers and become almost a classical Bowen's reaction series of basalt-andesite-dacite-rhyolite. However, many modeling results were inconsistent with the existence of hot suprasubduction mantle $\left(\geq 1400{ }^{\circ} \mathrm{C}\right)$ while the behavior of tracers prompted more intricate melting patterns.

In the 2000 through 2007, the ideas of the 1980s received new support, especially, from experiments at 3-6 GPa, which are the conditions appropriate to slabs beneath arc volcanoes (Johnson and Plank, 1999; Kessel et al., 2005; Martin et al., 2005; Rapp and Watson, 1995). Kelemen et al. (2004) in their review confirmed the major role of primitive andesitic magma in subduction zones but suggested some ideas different from the earlier model. Namely, (1) at least five depth levels of magma generation and reactions which may appear in different successions; (2) a more intricate slab geometry, with a flat stagnant slab in the upper mantle transition zone (layer C); (3) key role of super-critical liquid that forms at 5-6 GPa; (4) subduction erosion and delamination of thick lower crust as possible agents that involve lower crust into recycling and eliminate, at least partly, the pyroxenite cumulates stacked in intermediate chambers at the base of the arc crust (Kelemen et al., 2004).

We discuss these debatable issues with reference to both seismic tomography images of the crust and upper mantle and lava compositions in the Kuriles-Kamchatka subduction system synthesized according to ample recent evidence reported in (Bogatikov et al., 2010; Ermakov et al., 2011; Ivanov, 2008; Kelemen et al., 2004; Laverov et al., 2005).

\section{The Kuriles-Kamchatka subduction system: Geological background}

The Kuriles-Kamchatka arc in the northwestern Pacific (Fig. 2A) is the northern part of the world longest system which includes also the Japan, Izu-Bonin, and Marianna arcs and extends over $8000 \mathrm{~km}$ being associated with subduction of the Pacific plate.

In the Aleutian arc at the northern end of the system, the Cenozoic (46-54 Ma) oceanic Pacific plate is subducting along a zone with a large strike-slip component which becomes pure shear in the Commander Islands. The rate of oblique subduction is $6-7 \mathrm{~cm} / \mathrm{yr}$ beneath the Aleutian arc (Singer et al., 2007) but is faster $(7.5-8.2 \mathrm{~cm} / \mathrm{yr})$ under the Kuriles-Kamchatka arc (frontal motion) where the lithosphere reaches a Cretaceous age (90-120 Ma, or even $130 \mathrm{Ma}$ in the part that subducts beneath Japan). Subduction beneath the Izu-Bonin and Marianna arcs involves lithosphere as old as Jurassic (146-155 Ma) and has a slower rate of 6.0-7.6 cm/yr. Note that the rate of subduction does not correlate with slab age, being the fastest $(8.2 \mathrm{~cm} / \mathrm{yr})$ in the case of Cretaceous (120 Ma) lithosphere in the southern Kuriles and the slowest (6 cm/yr) in the eastern Aleutian (46 Ma) and Marianna (155 Ma) arcs. The slab may remain relatively hot in the Aleutian segment only but is cold and homogeneous elsewhere, with its thickness more than $100 \mathrm{~km}$.

The Aleutian arc comprises three segments, according to the backarc structure and the lava compositions (see below): (i) the East Aleutian segment east of Adak island where subduction is beneath the Alaska continental block while the compositions are surprisingly rather basaltic (andesites constitute no more than 30-40\%); (ii) the West Aleutian segment where the Pacific plate subducts beneath the Mesozoic Bering Sea plate (a remnant of Kula) and andesites predominate over basalts; (iii) a segment meeting the basins in the west separated from the Bering Sea by the Shirshov (Olyutorsky) and Bowers ridges. The Pacific plate is involved in strike-slip motion along the ends of the Aleutian and Commander trenches, while the Shirshov (Olyutorsky) and Bowers ridges may be remnants of a Late Cretaceous-Paleogene arc.

The Kuriles-Kamchatka arc consists of the Kamchatka and Kuriles segments (Fig. 2A). Subduction in Kamchatka (and northern Kuriles) is beneath the Kamchatka-Okhotsk continental block (KOB), and the related volcanism acts as violent explosive eruptions of andesite, dacite, and rhyolite lavas producing large calderas. The Central and Southern Kuriles subduct beneath the Okhotsk Sea block (OSB, Fig. 2A) 


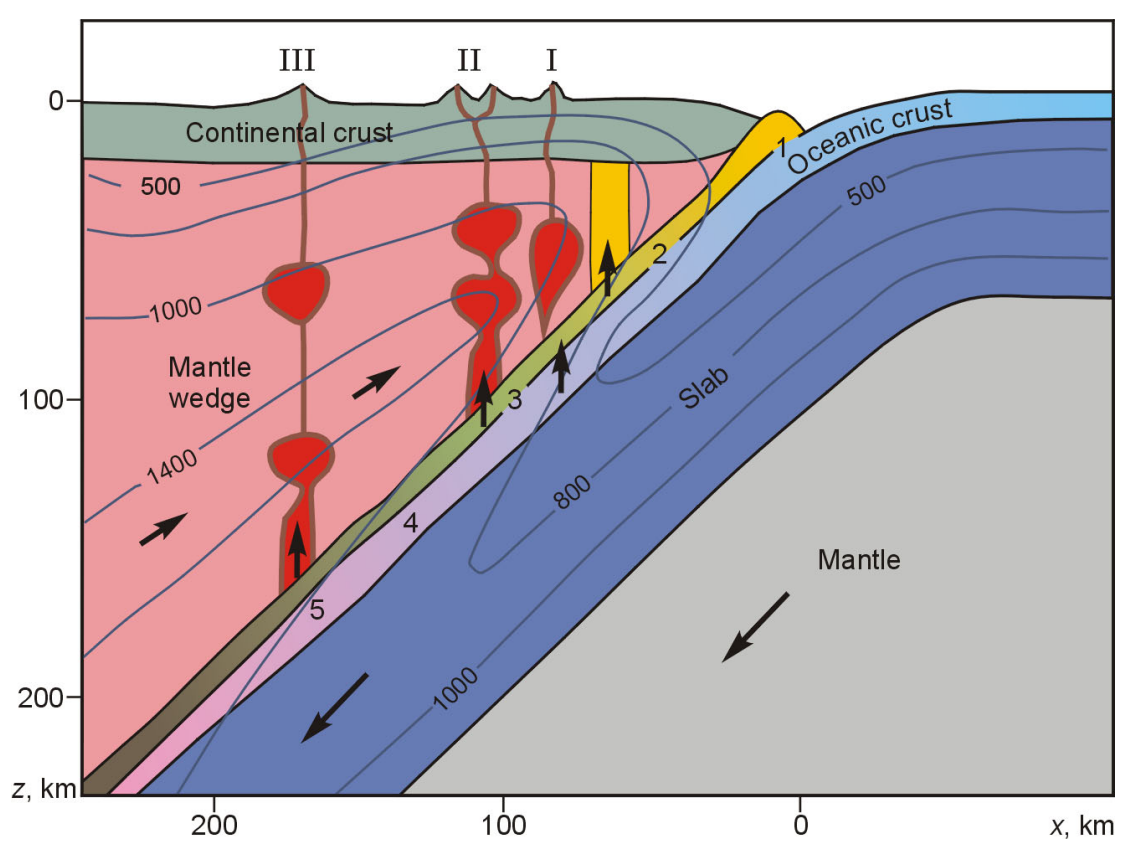

Fig. 1. Model of a subduction zone and related volcanism, modified after (Dobretsov, 2010). See text for explanation. Blue lines with numerals show predicted temperatures $\left({ }^{\circ} \mathrm{C}\right)$.

A

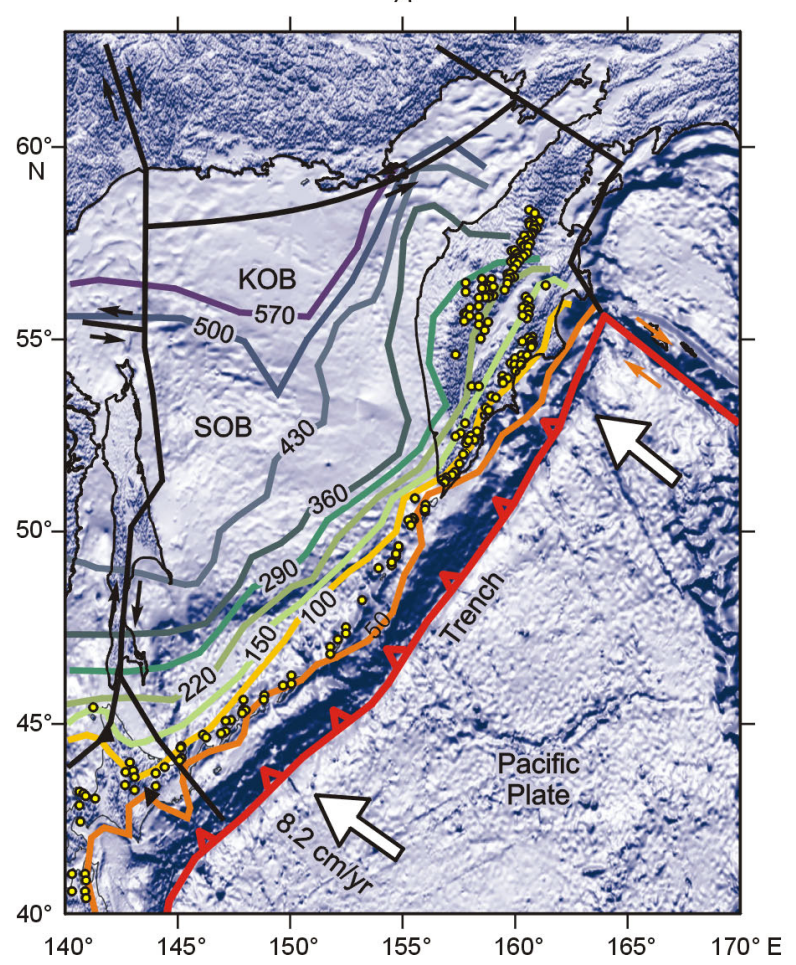

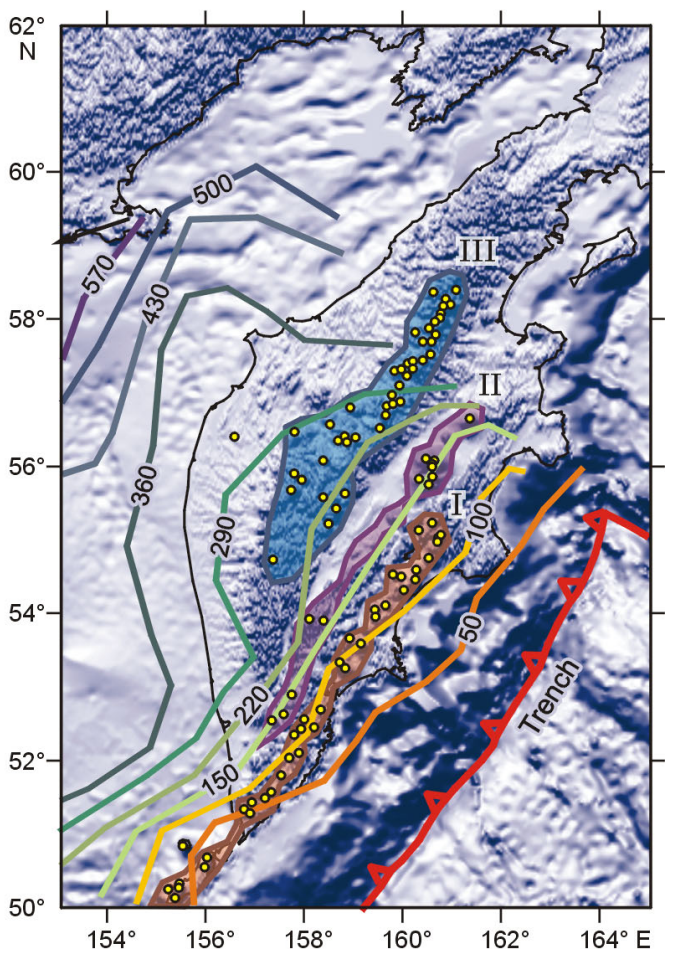

Fig. 2. Model of subduction beneath Kuriles-Kamchatka arc $(A)$ and Kamchatka Peninsula $(B)$. Yellow dots are active volcanoes; colored lines contour depths (km) of slab top, from tomography (Koulakov et al., 2011a). OSB = Okhotsk Sea block, KOB = Kamchatka-Okhotsk block. White arrows show direction of Pacific plate. I-III are belts of volcanism front: East volcanic belt (I), Klyuchevskoy belt (II), Sredinny Range belt (III).

consisting of young ( $<15 \mathrm{Ma})$ oceanic lithosphere within the South Okhotsk trench and thick Mesozoic oceanic lithosphere beneath the remaining OSB. The latter possibly formed upon a fragment of an oceanic rise that accreted to $\mathrm{KOB}$ in the latest Cretaceous (Bogdanov and Dobretsov, 2002). The percentage of basaltic lavas in this segment reaches 30-50\%.

In the consideration below, we focus on the Kamchatka segment as an example of andesite-dacite-rhyolite volcanism 


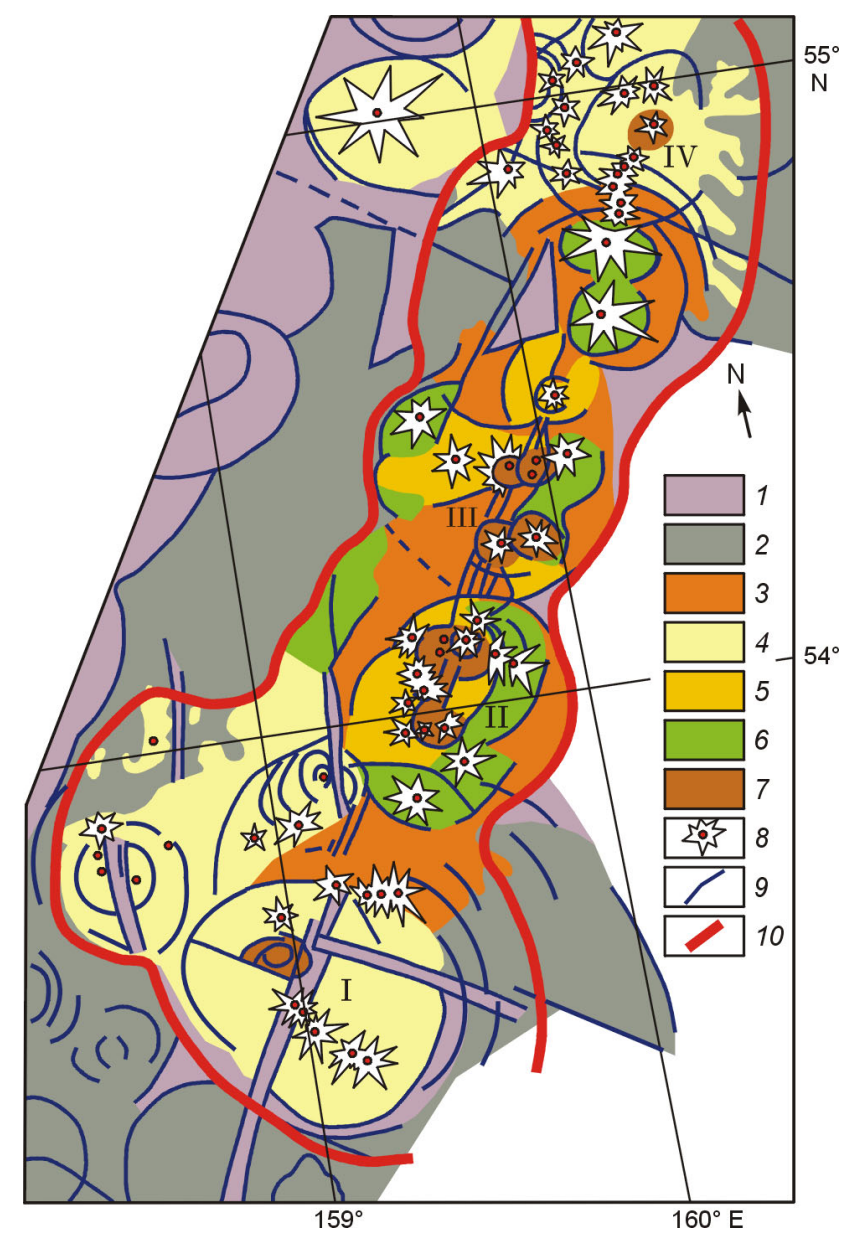

Fig. 3. Generalized map of East volcanic belt, Kamchatka. 1, depressions, including Lake Kronotskoye; 2, pre-Pleistocene basement; 3, ignimbrite and felsic tuff; 4, Pleistocene and Quaternary volcanics; 5, dacite; 6, basalt; 7, extrusives; 8 , large calderas; 9 , faults; 10 , outer border of volcanic complex. Roman numerals are volcanic centers: Avacha (I), Karymsky (II), Uzon (III), Gamchen (IV), modified after (Fedotov and Masurenkov, 1991).

responsible for juvenile continental crust production, though data from other segments will be mentioned as well for comparison. The Kamchatka segment (Fig. 2B) comprises three belts of Neogene-Quaternary volcanism: the Eastern volcanic belt running from the southern part of the peninsula to the Northern Kuriles; the Klyuchevskoy belt (Shiveluch, Klyuchevskoy, and Nikolka group of volcanoes) at the junction with the Eastern belt; and the back belt of the Sredinny Range with mainly basaltic volcanics and some local occurrences of andesites and dacites.

The Eastern belt (from Avacha to Gamchen volcanoes as shown in Fig. 3) includes eighteen active volcanoes and five large concentric calderas (up to $120 \mathrm{~km}$ in diameter) that likewise form separate volcano groups (Avacha, Karymsky, Uzon, Gamchen). The fifth group (Kronotsky, Krasheninnikov, and a triangular depression of Lake Kronotskoye with its submarine volcanoes) lies between the Gamchen and Uzon groups. The main caldera event gave rise to a large ignimbrite belt $\left(160 \times 80 \mathrm{~km}\right.$, about $\left.13,000 \mathrm{~km}^{2}\right)$ that extends from the northeastern foot of the Klyuchevskoy group as far as the
Kronotsky structure and the surroundings of Lake Kronotskoye (Fig. 3). The compositions of the ignimbrites are reported below.

The large calderas of 100-120 km enclose smaller concentric rings like the ones shown in Fig. 4 for the Karymsky complex. The external arcs make up the Zhupan ring structure of $100 \mathrm{~km}$ in diameter with the $30 \mathrm{~km}$ Karymsky structure and still smaller rings from 1 to $7-10 \mathrm{~km}$ inside. Several volcanoes (Karymsky, Malyi Semyachik, and a new eruption center in Lake Karymskoye) are currently active (Fig. 4).

The calderas underwent the stages of pre-caldera (I), caldera (II), and post-caldera (III) in the Middle-Late Pleistocene (Fig. 5), with two substages in I which produced, respectively, ignimbrites and ash tuffs (Ia) and rhyolite-dacite lava flows and domes ( $\mathrm{Ib}$ ). Generally, the history of the past $200 \mathrm{kyr}$ included two caldera stages (Ib and III) when 200-300 m thick dacite lavas were deposited during each event, the total thickness being more than $1000 \mathrm{~m}$ (Fig. 5). The material erupted over that time span exceeds $11,000 \mathrm{~km}^{3}$ in total and has been mainly dacitic and andesitic, while the eruption volume for the past $600 \mathrm{kyr}$ was only $2200 \mathrm{~km}^{3}$ of mostly basaltic lavas (Laverov et al., 2005).

The pre-caldera and post-caldera complexes contain also mafic rocks: they are no more than $30 \%$ in the Uzon structure but reach $50-60 \%$ in the Semyachik one. Volcanoes with large basalt percentages are commonly restricted to the periphery. Large calderas form by voluminous eruptions of felsic pyroclastics (ignimbrites and dacites). Volcanoes in the Klyuchevskoy group are likewise of two types: either mainly basaltic (Klyuchevskoy, Ushkovsky, Tolbachik) or andesiticdacitic (Zimina) or purely andesitic (Bezymyanny, Udina); the latter are in the center of the group while the basaltic ones are on the periphery.

Details of basaltic, basaltic-andesite, and andesite-daciterhyolite eruptions alternating in space and time are provided below after the discussion of the velocity structure under the Kuriles-Kamchatka arc and under separate groups of volcanoes.

\section{Velocity structure of crust and upper mantle beneath volcanic arcs}

Recording signals from natural earthquakes (passive seismic methods) is the most effective tool to study crustal and mantle sources of volcanism. Of numerous existing approaches, we confine to seismic tomography implying inversion of compressional- and shear-wave $(P$ and $S)$ earthquake traveltimes, to distances from thousands to tens of kilometers.

\section{Regional tomography of mantle structures}

The regional-scale velocity structure down to the transition zone $(670 \mathrm{~km})$ and deeper in the area of subduction has important implications for the geometry of slabs and related lithospheric processes that control the formation of volcanic arcs. Regional tomographic models reported in (Koulakov et 


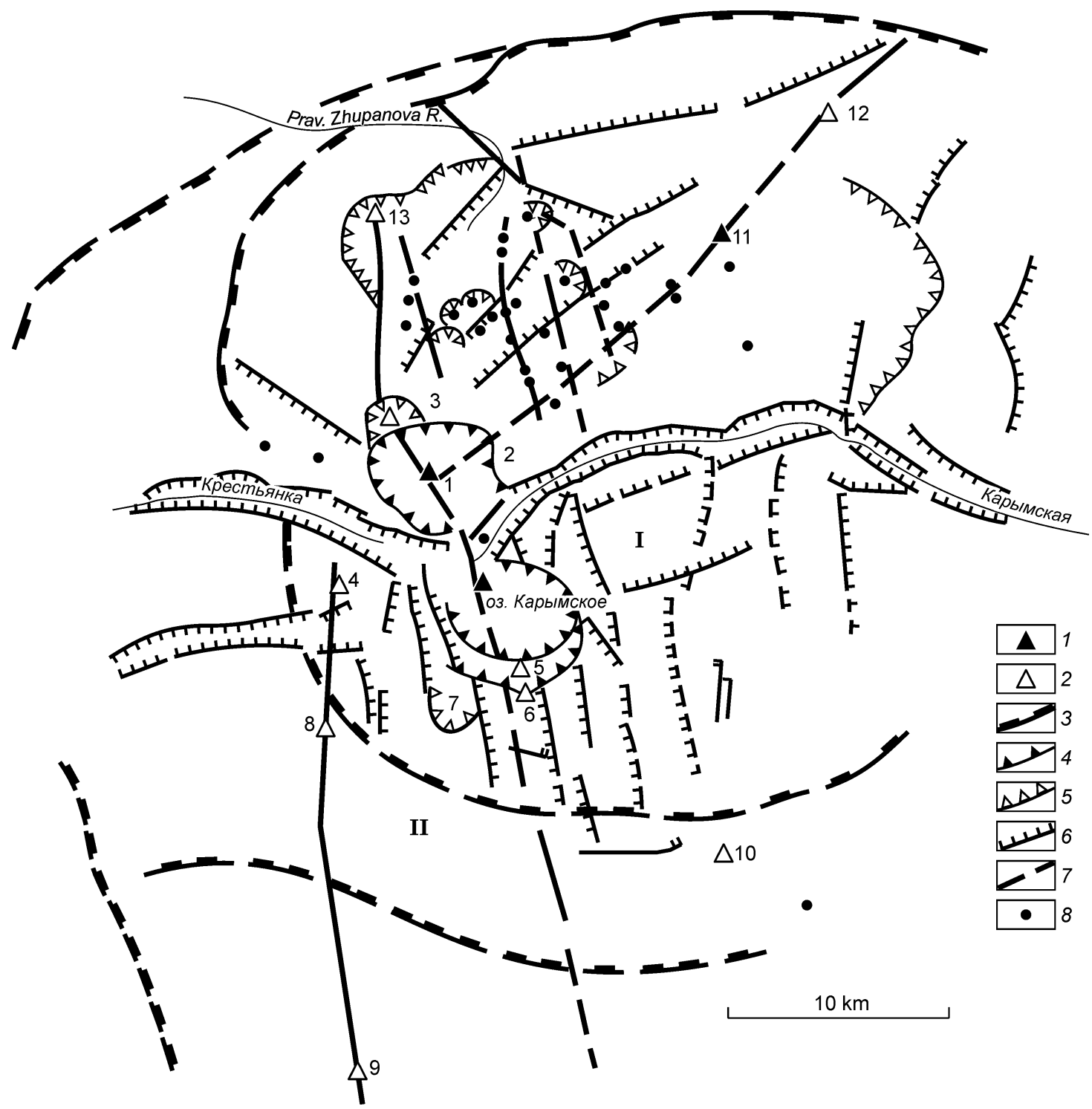

Fig. 4. Generalized tectonics of Karymsky volcanic complex. 1, 2, active (1) and dormant (2) volcanoes; 3, fault borders of Karymsky (I) and Zhupan (II) ring structures; 4, calderas; 5 , destroyed volcanic edifices and ancient calderas; 6 , faults with fault scarps; 7 , normal faults; 8 , monogenetic volcanic cones. Arabic numerals stand for names of volcanoes: Karymsky, active center (1); Karymsky, Somm (2); Dvor (3); Razlatyi (4), Akademii Nauk (5), Odnobokiy (6), Belyankin (7), Krainiy (8), Zhupanovskie Vostryaki (9), Ditmara (10), Malyi Semyachik (11), Berezovy (12), a new eruption center, Tokarev crater (13), modified after (Ivanov, 2008).

al., 2002; Koulakov and Sobolev, 2006) were obtained by inversion of $P$ and $S$ traveltimes borrowed from worldwide seismological catalogs. In the suggested scheme, rays selected for inversion have to travel, at least partly, through the study area. The data may include local earthquakes in the area of interest recorded at teleseismic stations of global networks, as well as teleseismic events recorded by local stations. This approach allows reliable results in the case of sparse coverage of seismic stations, which is essential for most of subduction zones (Koulakov et al., 2006, 2011a).

The velocity structure of the Kuriles-Kamchatka arc was modeled using global data (Fig. 6) (Koulakov et al., 2011a). In the present study, over 3 million of $P$ and $S$ earthquake traveltimes from the catalog of the International Seismological Center (2001) of 1964 through 2007 were inverted using the adaptive grid algorithm. The grid was placed inside the study area, according to the ray density down to a depth of $1100 \mathrm{~km}$. The inversion quality, resolution, and noise were checked in several tests.

The recorded $P$ and $S$ velocity anomalies consistently image subduction of a high-velocity oceanic lithosphere beneath the Kuriles-Kamchatka arc. This agrees generally with earlier results (Zhao et al., 2009, 2010), but our model predicts somewhat different behavior of the slab in the northern and southern arc segments (Fig. 6). Subduction is relatively lowangle (about $40^{\circ}$ ) in the South Kuriles, near Hokkaido; then the slab flattens down and moves horizontally westward in the transition zone between 500 and $670 \mathrm{~km}$. In its upper part (above $300 \mathrm{~km}$ ), the slab is as thick as 200-250 km, which is evidence of almost twice slower motion after the onset of 


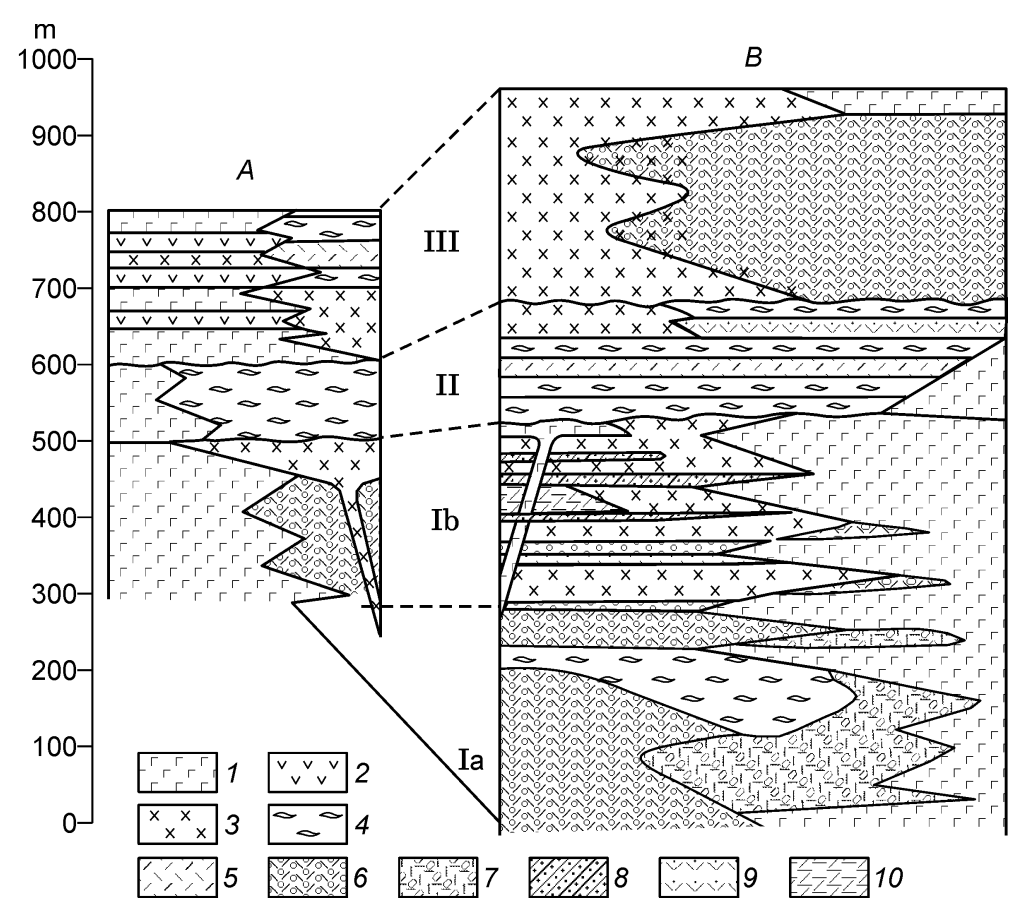

Fig. 5. Composite geological cross sections of the area of Semyachik (A) and Uzon-Geizer (B) groups of volcanoes. 1, basalt; 2, basaltic andesite and andesite; 3 , dacite and liparite; 4 , ignimbrite; 5 , pumiceous tuff; 6 , rather pumiceous tuff, with some exotic material; 7 , pillow basalt tuff breccias; 8 , sinter; 9 , layers of non-baked pyroclastics inside ignimbrite lava flows; 10, rather pumiceous lacustrine deposits. Ia, Ib, II, III are explained in text, modified after (Erlikh, 1973; Laverov et al., 2005).

subduction, given that the expected thickness of the oceanic lithosphere must be about $100 \mathrm{~km}$. Therefore, there is push from the oceanic plate that drives subduction against the resistance of the sinking slab. Interestingly, the Benioff seismicity within the thick lithosphere of the upper $300 \mathrm{~km}$ is in the middle of the high-velocity zone instead of being restricted to the slab top as it usually happens. This may indicate slab doubling as an old subduction zone dies out and a new one forms in its immediate vicinity (Fig. 7).

Subduction beneath the North Kuriles and South Kamchatka is steeper (about $50^{\circ}$ ), and the slab is markedly thinner at the $300 \mathrm{~km}$ depth than in the south. Below $400 \mathrm{~km}$, the slab is a large high-velocity body traceable also under the transition zone. The slab geometry in this case indicatespull from the sinking part which drives the subduction in this segment. This quite different subduction mechanism is due to a greater slab density related to eclogitization and more or less complete removal of melts along the arc.

Thus, as the example of the Kuriles-Kamchatka arc demonstrates, subduction is quite a complicated mechanic system, and its modeling in 2D as a "plane conveyor" is too simplistic. There are many factors that may be responsible for the changes in slab behavior along the subduction zone, especially, melting and melt migration, as well as phase transition in the sinking oceanic lithosphere. The same agents give rise to volcanic arcs and cause compositional variations in the erupted material.

We may invoke another key point in the regional mantle structure to explain the volcanism patterns, namely, a gap (plate break) between the Kamchatka and Aleutian slabs, which is prominent in the tomographic section of the $220 \mathrm{~km}$ depth (Fig. 6A). One has to bear in mind in this respect that this is exactly the place where the slab subducts beneath the Obruchev Ridge, on the extension of the Emperor's Ridge (Hawaii hot spot). This very interaction of two parts of the subduction zone may account for the broad-scale and uneven activity of volcanoes in the Klyuchevskoy group located near the Kamchatka slab edge. Below we provide more details of the deep structure and volcanism in this group of volcanoes.

\section{Local tomography of the Klyuchevskoy group of volcanoes}

The Klyuchevskoy group of volcanoes stands out in its activity and diversity, with almost all kinds of volcanism from Hawaii-type fissure eruptions to andesitic explosive (Peleanor Plinian-type) volcanism fitting a small area of $\sim 80 \mathrm{~km}$ in diameter (Fig. 8). The coexistence of volcanoes of different eruption types and lava compositions must be due to an intricate pattern of intermediate reservoirs where crustal and mantle material can mix up and react.

The Kamchatka division of the Geophysical Surveys of the Russian Academy of Sciences has been monitoring local seismicity around the Klyuchevskoy volcanoes since long ago, but it was not until the early 2000-s that the number of stations became sufficient for tomography. From 1999 through 2009, about one million $P$ and $S$ arrivals from more than 80,000 events were collected. However, it has been problematic to process all data simultaneously: Minimization of traveltime residuals possible in bulk inversion is very small, i.e., there is no single model to account equally well for all records over 

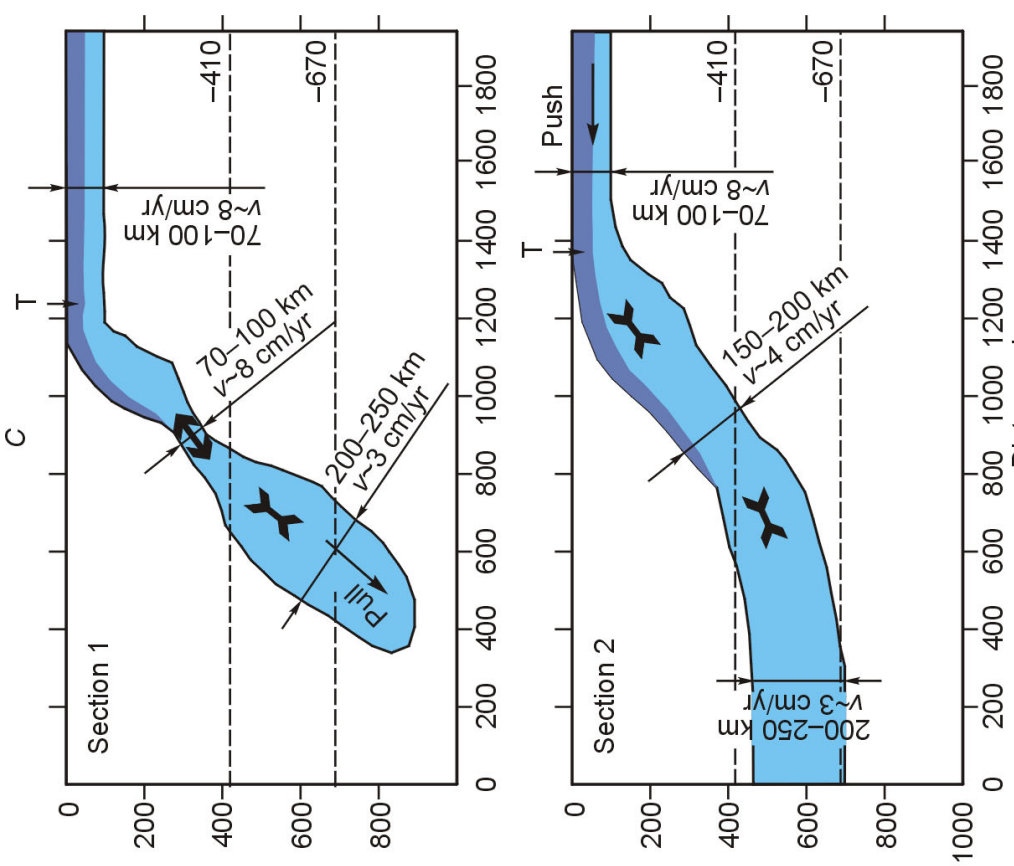

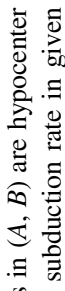

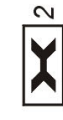

$\stackrel{0}{0}: \stackrel{0}{0}$

㐫芯

.

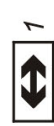

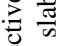

贾,

:

\&

(ิ)

造

要

言 U

उ. $\Xi \cdot \frac{0}{0}$
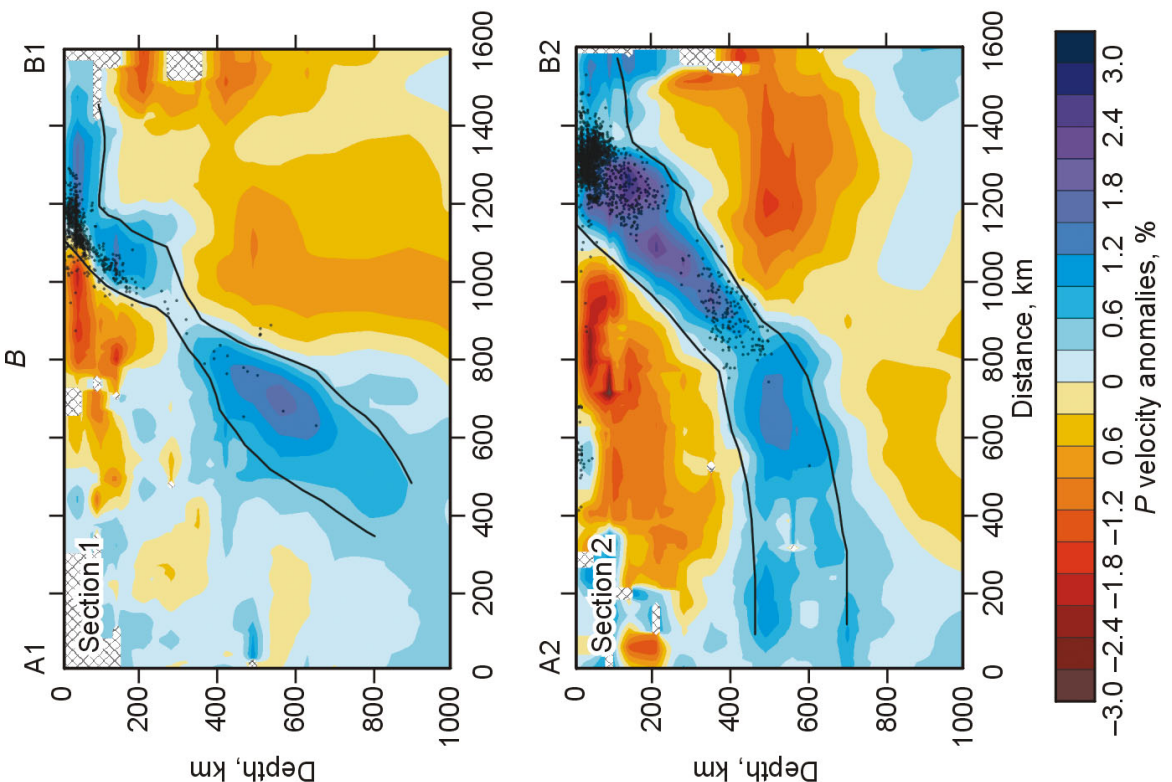

言-

它缡

政

䒕 สิ

ปิ

言递

ए

बi.

ष

实

휼 흘

莺造总

可 흘

节言

造

ङु

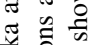
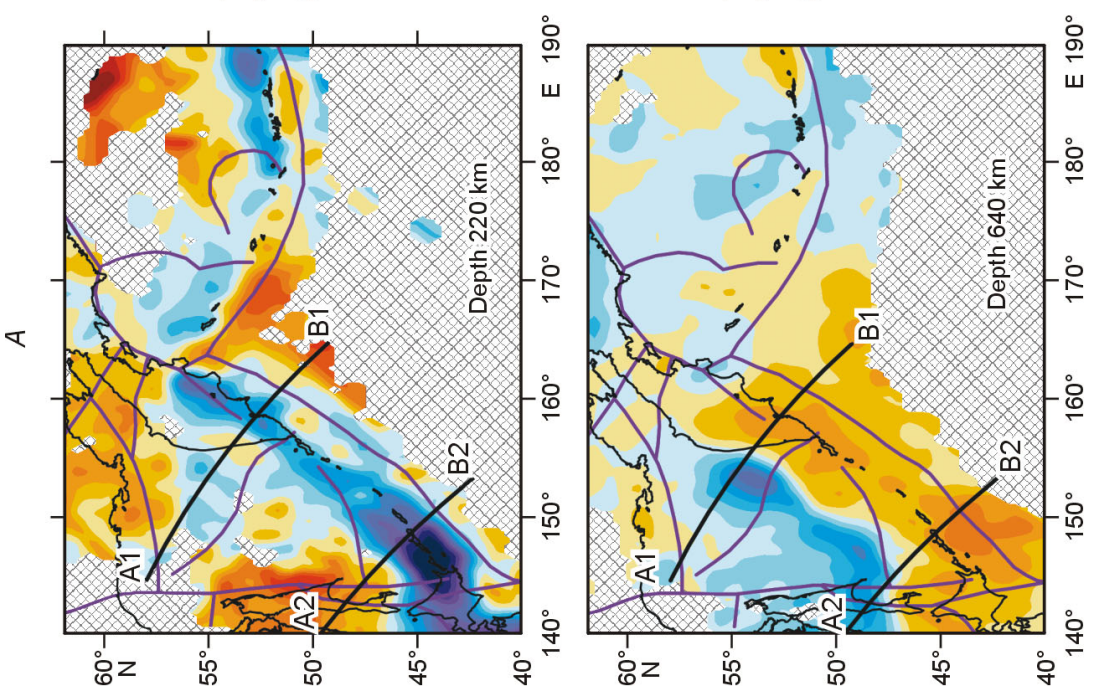

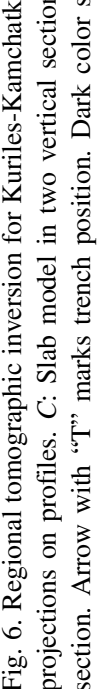




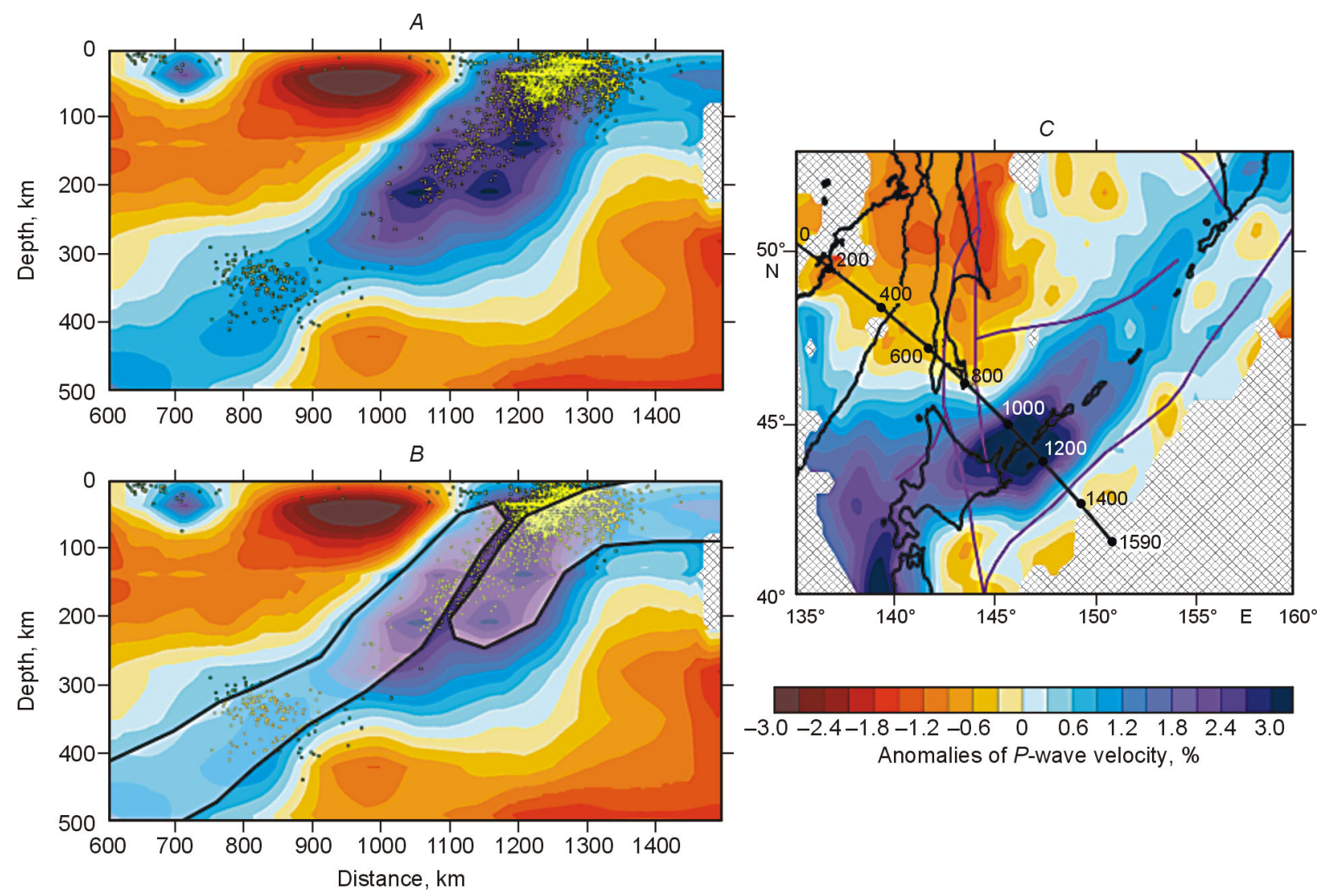

Fig. 7. A tomographic model of Southern Kuriles, a fragment, after (Koulakov et al., 2011a). A: vertical section to $500 \mathrm{~km} ; B$ : formation model of a new subduction zone; $C$ : horizontal section at $220 \mathrm{~km}$ and location of profile. Yellow dots are hypocenters.

the 1999-2009 time span. The inversion quality improves, however, for yearly data subsets, which means that the seismic structure changes with time. The variations are of special interest with respect to volcanic activity for the observation period. For instance, the simultaneous onset of activity at Klyuchevskoy and Bezymyanny in 2005 provided a unique opportunity of tracing processes in the Earth's interior in different eruption phases (preparation, activation and relaxation).

The velocity structure beneath the area right before the eruption of 2004 was a subject of a separate study (Koulakov et al., 2011b). The image of Fig. 9 was obtained based on data in 2003 and it was almost identical to that of 2004. The seismic model computed using the LOTOS local tomography algorithm (Koulakov, 2009) shows an anomaly with extremely high $v_{P} / v_{S}$ ratio reaching 2.2 below $25 \mathrm{~km}$ near the Moho (Fig. 9). The coexistence of high $D$ velocities (composition proxy) and low $S$ velocities (phase state proxy) prompts the existence of a conduit which channels melt and/or fluid from mantle depths. Similar magma reservoirs at the crust base beneath some volcanic systems were predicted from geochemical data (Izokh et al., 2010). The material from the crustal base may be parent magma for all melts in the Klyuchevskoy system, and it may penetrate through crust following quite an intricate path. Magma sources appear within at least two more depth intervals (10-12 km and
0-5 km) in the crust immediately beneath Klyuchevskoy (Fig. 9), which is likewise consistent with rock compositions (Ariskin et al., 1995). Such a multi-level system accounts for the diversity of volcanism in the group. In each reservoir, magma can fractionate to different degrees and partly react with crustal material thus changing the compositions. Note that the migration paths of melts are often marked by earthquakes (Fig. 9).

All seismic models in the time-lapse series from 2001 through 2009 for the Klyuchevskoy group (Koulakov et al., 2012) show an abnormal $v_{P} / v_{S}$ ratio deeper than $25 \mathrm{~km}$, which represents the upper part of the mantle conduit (see above). The crust experiences significant changes with time during different stages of the Klyuchevskoy and Bezymyanny eruptions (Fig. 10). The pattern remained invariable till 2004 for at least three years (Fig. 10A), when two intermediate chambers existed at $10-12 \mathrm{~km}$ and $0-5 \mathrm{~km}$ beneath Klyuchevskoy, in addition to the mantle conduit.

However, a dramatic change occurred in 2005 (Fig. 10B): the average level of $v_{P} / v_{S}$ in the crust increased indicating input of large batches of melts/fluids to the system. There appeared a prominent $v_{P} / v_{S}$ anomaly underneath Bezymyanny connecting it directly with mantle reservoirs, which was not observed before. The shallow anomaly beneath Klyuchevskoy disappeared in 2005 while the deeper one (at 10-12 km) remained well pronounced. 


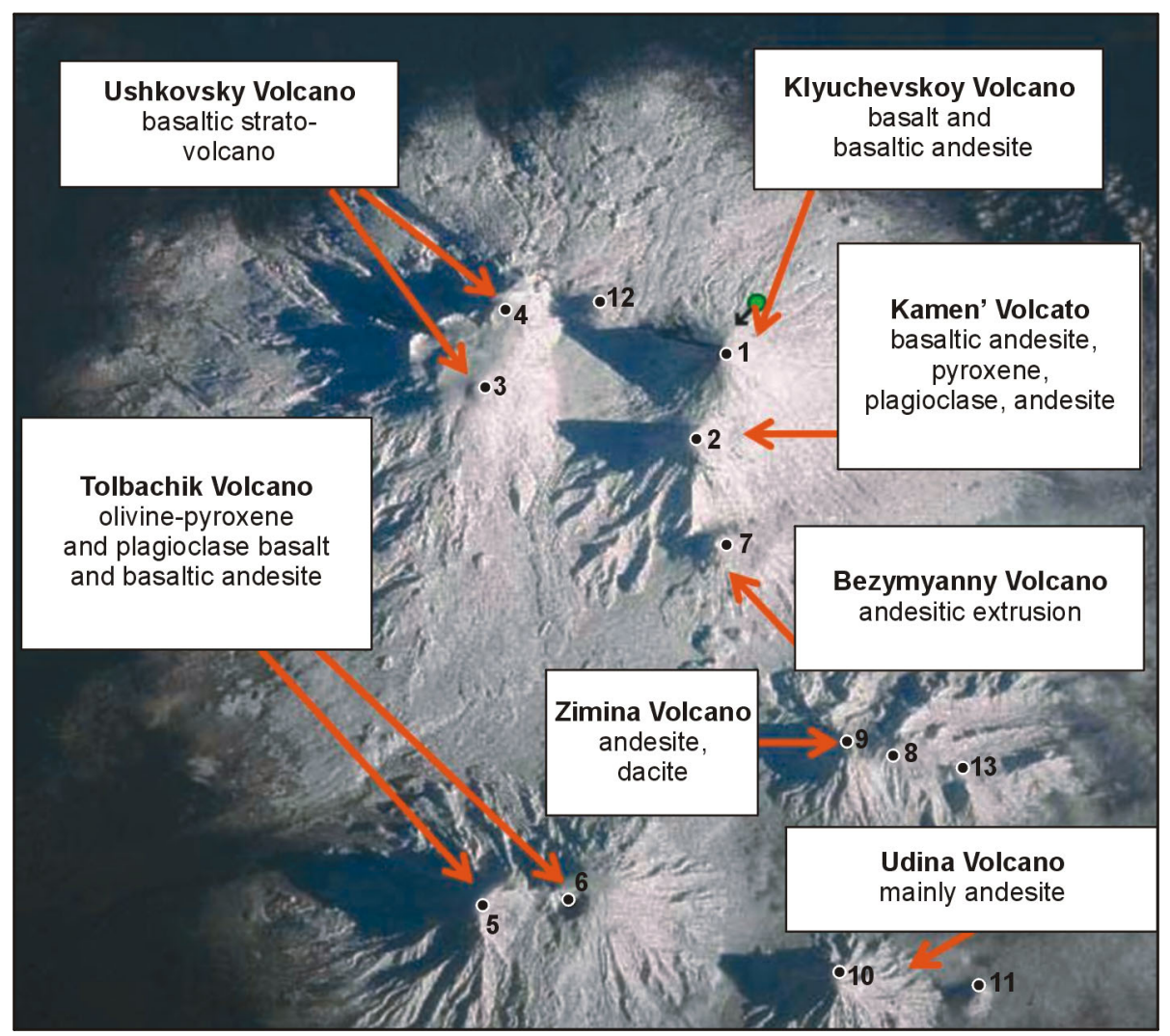

Fig. 8. Volcanoes of Klyuchevskoy group: a satellite image. Points numbered from 1 to 13 are volcanoes: Klyuchevskoy (1), Kamen' (2), Ushkovsky (3), Krestovsky (4), Ostryi Tolbachik (5), Plosky Tolbachik (6), Bezymyanny (7), Ostraya Zimina (8), Ovalnaya Zimina (9), Bolshaya Udina (10), Malaya Udina (11), Sredniy (12), Gornyi Zub (13). White boxes show lava compositions typical of some respective volcanoes.

There was another dramatic change, in 2006 (Fig. 10C): the $v_{P} / v_{S}$ ratio in the crust decreased generally and all anomalies attributed to the intermediate reservoirs disappeared. One source reappeared only three years later at a depth of $10-12 \mathrm{~km}$.

Which may be the causes of these changes in seismic structure beneath the Klyuchevskoy volcanoes? Migration of such large volumes of material is unlikely. Even minor displacement of $\mathrm{km}^{3}$-scale amounts of material obviously would produce instrumentally detectable deformation on the surface. Inasmuch as no deformation of this kind has been observed, the variations in crustal velocity ratios may record changes in stress and strain, or fluid migration, or phase state change. The mantle conduit influences largely the lower crust being responsible for active seismicity at the respective depths. Seismogenic crust till 20-30 km implies high stress giving rise to fractures that can channel fluids and/or melts accumulated at the crust base. Once getting into the intermediate chambers, the volatiles-rich agents decrease the melting point and thus increase the melting degree. On the other hand, the fluids that rise along fractures boil as a result of decompression to increase the pressure further and induce new fractures. The positive feedback drives an avalanche process which eventually ends up with an eruption.

After the "excess" melts and fluids erupt, the magma loses its volatiles (dries out), its melting point increases, and the melts that remain in intermediate chambers crystallize rapidly. It is exactly at this stage that the $v_{P} / v_{S}$ anomalies disappear. The sources of partially molten material can reappear a few years later, when new batches of fluids rise from the mantle.

Therefore, the shallow magma sources are dynamic systems with rapidly changing properties. At certain stages, they may consist of a sponge-like material rather than being melt-filled chambers with distinct walls. Propagation of fractures and migration of melts/fluids can change dramatically the rheology of this sponge within only a few years or even months. Note that with this mechanism, the sponge-like source may transform into well-defined intrusive chambers as the melt fraction grows.

\section{Feeding of volcanoes from the slab}

In the previous sections, we discussed regional and local tomography performed to study, respectively, the slab behavior and the subsurface immediately underneath volcanoes. Of special importance is also the regional velocity structure of an intermediate scale that allows insights into the role of the slab as a feeder of volcanic arcs. In this case the inversion applies to arrivals from earthquakes within the slab at stations on the surface at distances of a few hundreds of kilometers. The seismological network in Kamchatka is insufficient to provide reliable data, but one of us (I.K.) has had much experience in 

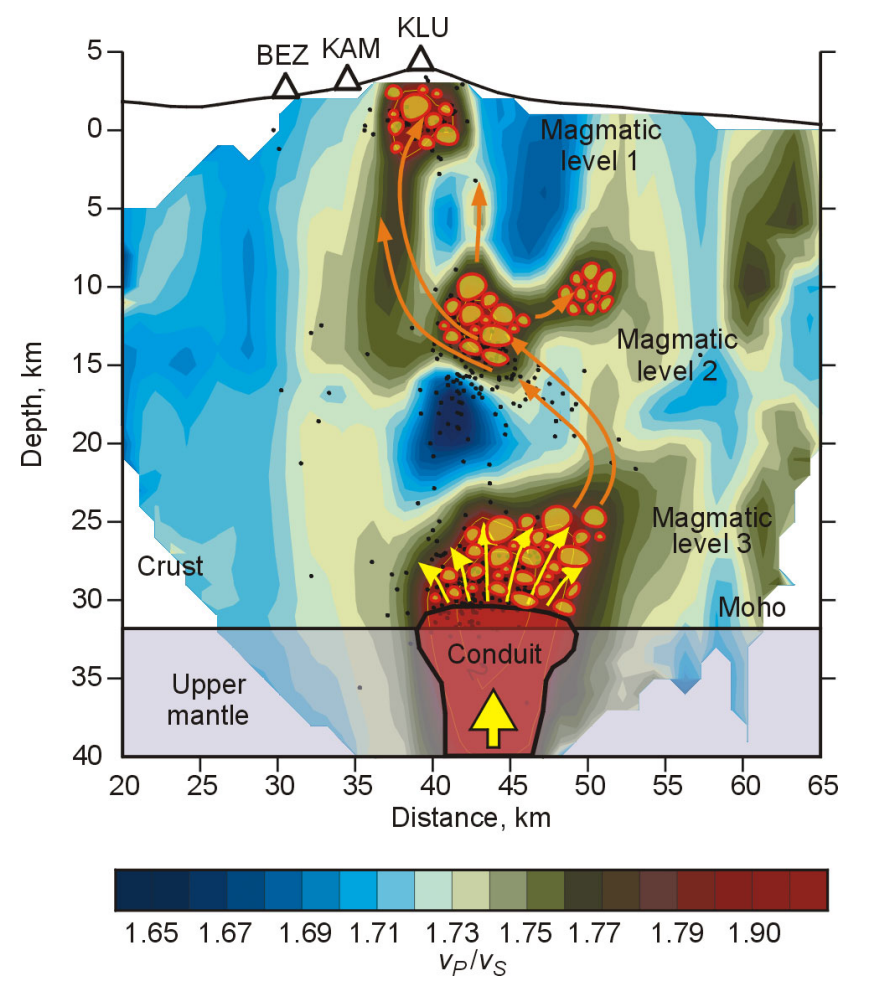

Fig. 9. Distribution of $v_{P} / v_{S}$ ratios in lithosphere beneath Klyuchevskoy and Bezymyanny along a profile collected in 2003. Black dots are projections of earthquakes on the profile. Zones of highest $v_{P} / v_{S}$ ratios presumably correspond to magma reservoirs (yellow bubbles). Abbreviations stand for volcano names: BEZ, Bezymyanny, KAM, Kamen', KLU, Klyuchevskoy. Arrows show possible migration paths of fluids and melts between the magma sources.

processing diverse high-quality data collected in international projects from most interesting subduction zones. Here we synthesize the results from three regions and discuss the implications for the structure of the Kamchatka subduction zone.

The first tomographic experiment was run in Sumatra, in one of youngest and largest calderas. A paroxysmal eruption of Toba about $74 \mathrm{kyr}$ BP ejected about $2800 \mathrm{~km}^{3}$ of tephra spread over an enormous area, and produced an oblong $70 \times 30 \mathrm{~km}$ caldera, which currently hosts a lake (Lake Toba). However, the caldera resurged as a result of ongoing crust movements, and Samosir Island emerged in the lake center, with lacustrine deposits on its surface risen to hundreds of meters above the water. Given that Toba underwent at least four catastrophic eruption events for the past $1.2 \mathrm{Ma}$, it must keep a very high hazard potential.

We inverted earthquake traveltimes collected along the international PASSCAL station deployment in 1995. Over the period of campaign surveys, portable seismographs recorded about 400 prominent earthquakes with corresponding $3377 P$ and $2462 S$ rays. Masturyono et al. (2001) processed those records but failed to find any significant features. We later reprocessed the same data using the LOTOS code (Koulakov et al., 2009a) and obtained a velocity structure corresponding to ongoing volcanism beneath the caldera. Namely, there are small zones of high $v_{P} / v_{S}$ ratios (1.87) in the crust beneath the active volcanoes standing out against the background of $v_{P} / v_{S}=1.62$, which may mark the locations of magma reservoirs.

The vertical section of $P$ residuals across the caldera (Fig. 11A) highlights links between processes in the slab and volcanic events on the surface. About $120 \mathrm{~km}$ deep, there is a dense cluster of earthquakes possibly related with physicochemical changes in the slab material (melting, outgassing, etc.). Between this cluster and Toba caldera, there is a vertical low-velocity zone of $P$ and $S$ waves and high $v_{P} / v_{S}$ ratios. Most of earthquakes beneath the caldera originate at about $30 \mathrm{~km}$, i.e., near the Moho, like beneath the Klyuchevskoy group of volcanoes (Fig. 10). The quasi-vertical low-velocity zone may trace the paths of melts and fluids that rise from the $120 \mathrm{~km}$ deep slab to feed the magma reservoirs beneath Toba.

Central Java is another area of high seismic and volcanic hazard in Indonesia. Mount Merapi is one of world most active volcanoes, with explosive eruptions continuing for at least 7000 years. In 2004 more than 100 seismic stations were installed in Central Java, onshore and offshore for better coverage, as part of the International MERAMEX Project. The passive (earthquake) data were complemented by active (offshore airgun shooting) experiments, and the two data sets were inverted jointly to fully utilize the advantages of both approaches (Wagner et al., 2007). The number of stations and events was sufficient for anisotropic tomography which allowed estimating velocity variations as a function of ray direction (Koulakov et al., 2007, 2009b).

A vertical section across the subduction zone, with Merapi volcano, obtained by the anisotropic inversion (Fig. 11B) images a reservoir next to the volcano fed from the slab at mantle depths via a low-velocity zone that connects the volcano with a cluster of earthquakes generated at the slab top. However, unlike the case of Toba caldera, the anomaly beneath Merapi dips at $\sim 45^{\circ}$. The tilt may be due to a considerable friction between the slab and the mantle wedge above it and the related shear stress (black lines in Fig. 11B). The stress zones are relatively weak and may channel fluids and melts rising from the mantle.

The anisotropy direction beneath the volcano is a feature worthy of note. The velocity anomalies are mainly vertical immediately under the volcano, most likely aligned with the conduits and dikes, but horizontal anisotropy predominates north of Merapi within an intense anomaly which may be its feeder. This pattern may record horizontal flows, layering, and sills, or horizontally oriented intermediate reservoirs.

In the Central Andes we chose as the third example, the Nazca oceanic plate subducts under the continent of South America. The related tectonic activity in the area consists in stripping the overlying lithosphere, trench migration, and eastward motion of the arc complexes. The area has been studied comprehensively by the GFZ research center (Germany). A large amount of data ( $D$ and $S$ traveltimes and attenuation) was collected for several years of seismic monitoring by a dense network of stations. Tomographic inversion of the data was reported in (Koulakov et al., 2006). 

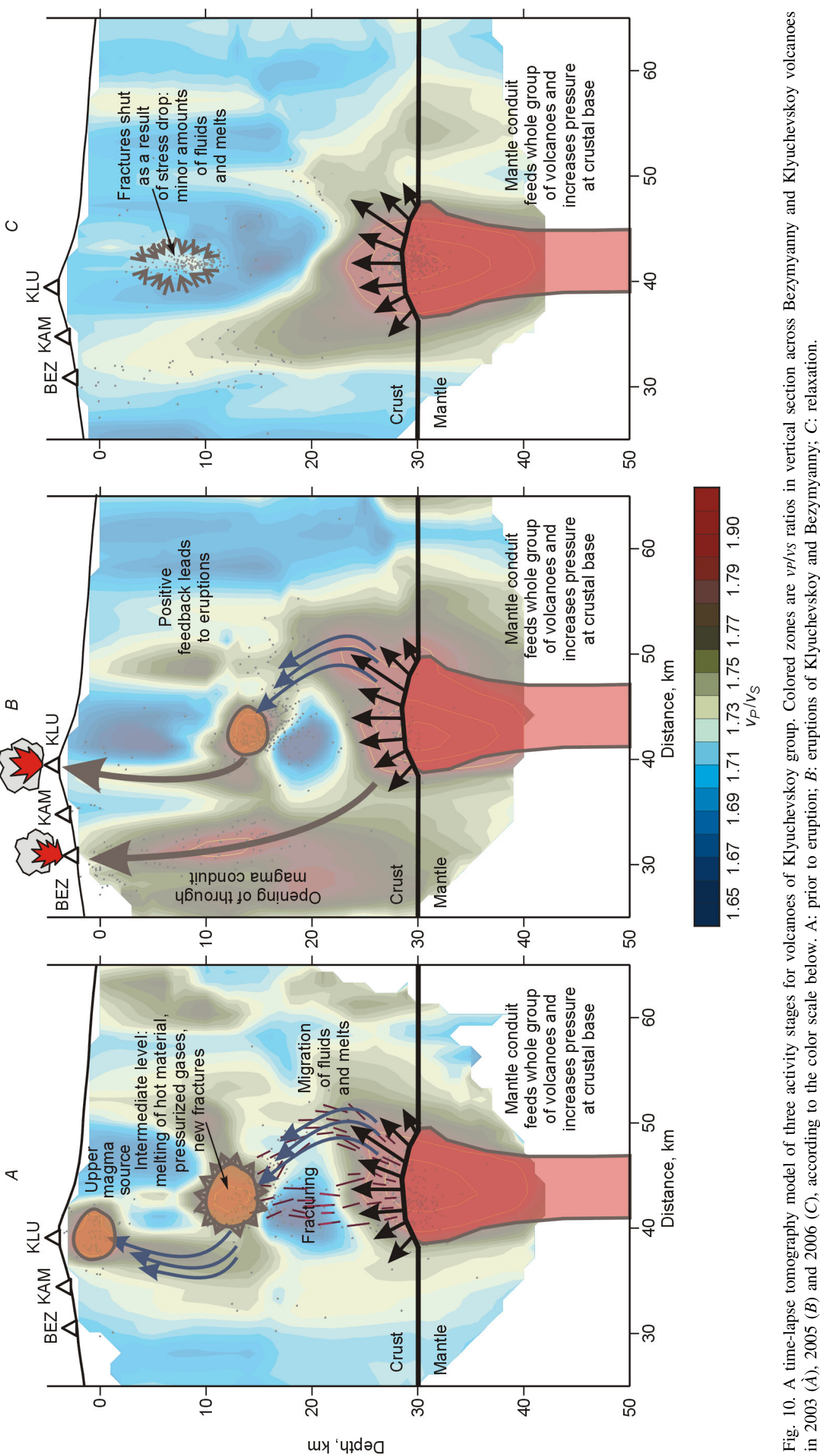
The vertical section across the Central Andes about $23^{\circ} \mathrm{S}$ (Fig. 11C) shows two distinct earthquake clusters at the depths 100 and $200 \mathrm{~km}$, both linked with arc volcanoes via $D$ and $S$ low-velocity zones. A low-velocity zone above the western cluster may correspond to the place where melts and fluids liberate from the slab. The anomaly moves eastward along the bottom of a high-velocity zone to its end where exactly the arc volcanoes form. Thus, the melts fail to erupt directly above their origin place, for some unknown reasons. Understanding these reasons requires special investigation into local geology and modeling, which may be a separate subject of research.

Fluids and melts release also from the deeper cluster ( 200 km), judging by the presence of a low-velocity zone which likewise rises toward the arc, either nearly vertically or with a small back tilt. Thus, there are two feeder zones from the slab in the area.

The three cited examples for different subduction zones demonstrate that volcanic arcs can feed from subducting slabs. The feeder channels are reliably traceable by means of seismic tomography, with advanced survey systems deployed in subduction zones. Note that the products of slab outgassing and melting follow different paths, their geometry being a function of the subduction regime (e.g., plate age, friction on the slab top, rheology of the overlying lithosphere, etc.).

\section{Levels of magma generation and reactions and distribution of dacitic-andesitic and basaltic lavas}

The reported local tomography images of the lithosphere beneath the volcanoes (Figs. 6, 7, 9-11) can provide clues to generation of primitive magma and the changes it undergoes on the way to the surface. As an illustration, we refer to the model by Ivanov (2008) shown in Fig. 12 in a slightly modified form. The model accounts for tholeiitic or calc-alkalic andesitic lava compositions in terms of the presence or absence of a magma reservoir in the middle crust, and we apply the model to volcanism in the Klyuchevskoy group of volcanoes. The model predicts magma generation at five levels: final dehydration and partial melting (at 100-130 km) where melts/fluids liberate from the slab and move to the mantle wedge (level 1); melting inside the mantle wedge where the rising fluids/melts react with hot mantle, i.e., contamination of melts with mantle material at $50-70 \mathrm{~km}$, the depth of the olivine buffer (level 2); melting in a large zone at the crust-mantle boundary and accumulation of material rich in volatiles, at 25-30 km (level 3); melting in the crust, at $10-15 \mathrm{~km}$, with possible crustal contamination of the molten material (level 4); melting in shallow crust immediately underneath volcanoes $(0-5 \mathrm{~km})$ and further assimilation and fractional crystallization of melts (level 5). On the other hand, the volcanoes may also feed directly from the source at the crust base (the conduit under the extrusive edifice). According to tomography, this mechanism may apply to Bezymyanny.

The compositions of type I and II andesites (Ivanov, 2008) are compared in Table 1 . Besides the listed parameters, type I lavas may also have high $\mathrm{Hf} / \mathrm{Yb}$ and $\mathrm{Th} / \mathrm{U}$ ratios. The classical explanation for the type II andesite compositions is in terms of crustal contamination in intermediate chambers at levels 4 and 5. However, seismic tomography and relative volumetric percentages of lavas of the two types allow a revision to the original model (Fig. 12), namely, excluding level 4 for type I and level 2 for type II, and different thickness of melting zones. The interpretation becomes different correspondingly.

In the course of 850 kyr history (Dobretsov, 2010; Laverov et al., 2005), volcanoes in Kamchatka produced about $8700 \mathrm{~km}^{3}$ of basaltic andesite to rhyolite lavas between 850 and $750 \mathrm{kyr}$ and then mainly basalts $\left(2200 \mathrm{~km}^{3}\right)$ from 750 to $250 \mathrm{kyr}$. However, the amount of material erupted since 250 kyr BP has exceeded $11,000 \mathrm{~km}^{3}$, while violent eruptions for the past $140 \mathrm{kyr}$ gave rise to large andesite, dacite, and rhyolite calderas. Basalts and basaltic andesites released between the caldera-forming events, in moderate volumes and by non-explosive mechanisms.

Kelemen et al. (2004) provide an exhaustive overview of compositions and amounts of volcanic products on the basis of more than 10,000 analyses, in which lavas are mostly basaltic in young oceanic arcs but mostly andesitic, dacitic, and rhyolitic in mature island and continental arcs (Fig. 13). This division (Kelemen et al., 2004) is, however, too simplistic. For instance, the relatively young Aleutian arc shows prominent dichotomy west and east of Adak Island, with large volumes of basaltic lavas in the east and prevalent andesites and dacites in the west. According to (Kelemen et al., 2004), basalts are not very abundant in Kamchatka, and according to (Bogatikov et al., 2010; Laverov et al., 2005) and our data, andesites and dacites make up $75-80 \%$ of eruption volumes. Note that basalts are almost absent, for instance, from the Central Andes. The approach of (Kelemen et al., 2004) has a drawback of calculating the statistics of published analytical data without due regard to the real amounts of erupted lavas. Thus calculated percentages of more felsic varieties become overestimated, and dacite-andesite compositions (>55 wt.\% $\mathrm{SiO}_{2}$ ) make about $2 / 3$ of the volume of plutonic rocks in the interior of arcs of any type (Fig. 13).

As theory and experiments predict (Dobretsov et al., 2001; Whitehead and Luther, 1975), the thickness $H$ of the melting zone in the upper part of the slab (Fig. 12) correlates with the size of volcanic groups and their spacing $l: l=n \times H(\mathrm{~km})$. This thickness $H$ reaches $20 \mathrm{~km}$ at $n$ about 5 and $l$ about $100 \mathrm{~km}$ (see, for example, the spacing of volcanic centers in Fig. 3 and the size of the Klyuchevskoy group in Fig. 9). Melt in such a thick melting zone reaches a critical amount and begins rising rapidly, in a plume, directly from the subduction zone (level 1) to the intermediate chamber at the crust-mantle boundary (level 3), past level 2, i.e., the rising melt has no time to react with the ambient mantle. On the other hand, intermediate sources at levels 4 and 5 arise right before eruption events and have short life spans.

Thus, type I corresponds to relatively rare non-explosive eruptions of basaltic-andesitic lavas, as it happened during the 750-250 Ma time span in Kamchatka and in the case of most eruptions in oceanic arcs, while type II represents voluminous, 

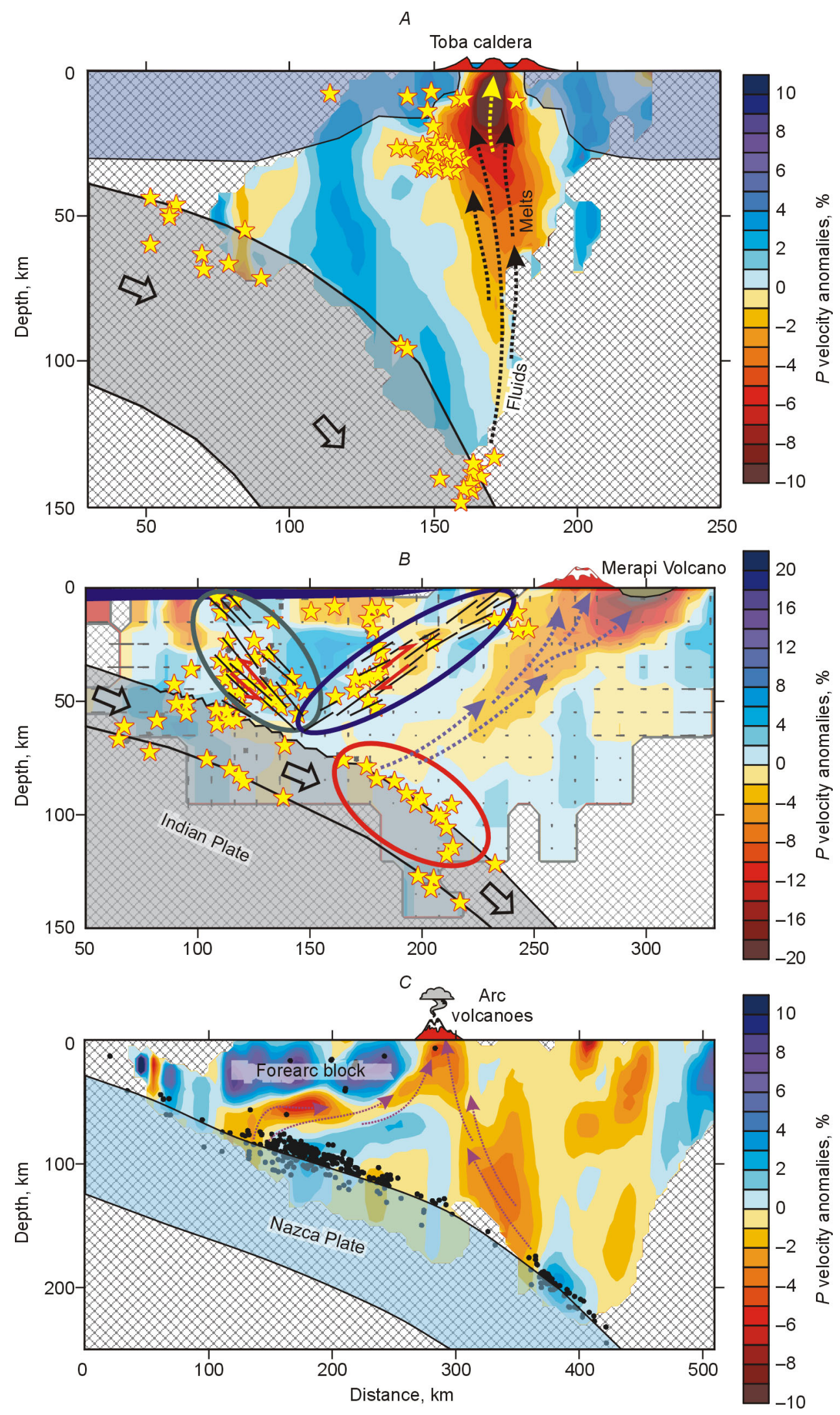

Fig. 11. Vertical seismic sections for three subduction zones. $A$ : Toba caldera, Sumatra; $B$ : Mount Merapi, Central Java; $C$ : across Central Andes, at $23^{\circ}$ S. Projections of earthquakes are shown as asterisks in $A$ and $B$ and as black dots in $C$. Arrows show possible migration paths of fluids and melts. 
Table 1. Compositions of type I and II andesites, modified after (Ivanov, 2008)

\begin{tabular}{lll}
\hline Parameter & Type I (tholeiite series) & Type II (calc-alkaline series) \\
\cline { 2 - 3 } & $\begin{array}{l}\text { Pyroxene andesite, clinopyroxene in phenocrysts with lower Ca } \\
\text { contents; pigeonite present in matrix }\end{array}$ & Hornblende-pyroxene and hornblende andesite, rare pigeonite \\
\hline $\mathrm{SiO}_{2}$, wt. $\%$ & $57-59$ & $59-63$ \\
$\mathrm{\Sigma FeO}$ & $>7$ & $<7$ \\
$\mathrm{Ba} / \mathrm{Sr}$ & $<1$ & $>1$ \\
$\mathrm{Enrichment}$ & $\mathrm{Mn}, \mathrm{V}, \mathrm{Co}, \mathrm{Zn}, \mathrm{Cr}, \mathrm{Ti}, \mathrm{Sr}, \mathrm{Sc}$ & $\mathrm{K}, \mathrm{Na}, \mathrm{Li}, \mathrm{Rb}, \mathrm{Ba}$ \\
${ }^{87} \mathrm{Sr} /{ }^{86} \mathrm{Sr}$ & $0.7030-0.7032$ & $0.7032-0.7037$ \\
${ }^{143} \mathrm{Nd} /{ }^{144} \mathrm{Nd}$ & $0.51309-0.51314$ or higher & $0.51306-0.51311$ \\
$\delta^{18} \mathrm{O}, \%$ & $4.6-5.7$ & $7.3-7.7$ \\
\hline
\end{tabular}

sometimes catastrophic, caldera events like those in the past $140 \mathrm{kyr}$ in Kamchatka or in Sumatra and, possibly, most of Andean-type events.

Furthermore, the lavas of types I (mainly basaltic) and II (mainly andesitic and dacitic) differ also in the amount of cumulates stacked at level 3 in the lower crust. See Fig. 14 where the experimental data and low-magnesian andesite (LMAs) and high-magnesian adakite and basaltic andesite (HMAs) compositions are plotted in the $\mathrm{SiO}_{2}$ vs. $\mathrm{Mg \#}$ coordinates. According to experiments at 3.2 and $3.8 \mathrm{GPa}$, primitive andesites correspond to the compositions of adakite veins in peridotite (Kelemen et al., 2004; Kepezhinskas et al., 2002; Martin et al., 2005), while $\mathrm{SiO}_{2}$ is about 65 wt.\% and $\mathrm{Mg} \#$ is no higher than $40-50 \%$. On the other hand, $\mathrm{SiO}_{2}$ is only 52-55 wt.\% and $\mathrm{Mg \#}$ reduces to $\sim 0 \%$ in primitive basalts. The same contents are assumed for primitive high-Al basalt in (Kelemen et al., 2004): 52 wt. $\% \mathrm{SiO}_{2}$ and 70\% $\mathrm{Mg \#}$. In Fig. 14, B, primitive andesite is presumed to contain 55-57 wt. $\% \mathrm{SiO}_{2}$ and about $70 \% \mathrm{Mg}$, which corresponds in Fig. 14, A to hybrid melt and HMAs. Arrows in the field of LMAs in Fig. 14, A indicate possible fractionation paths in the source at level 3 (Fig. 12), at a depth about $30 \mathrm{~km}$.

The model of Fig. 14, B, modified after (Kelemen et al., 2004), shows predicted percentages of primitive basalt and andesite relative to differentiates and cumulates in the form of pyroxenite (or melanogabbro) in a chamber at a depth of $30 \mathrm{~km}$. Provided that cumulates reach this or a slightly larger volume, primitive basalt may give rise to andesite with 55 wt. $\% \mathrm{SiO}_{2}$ and $40 \% \mathrm{Mg \#}$. Formation of differentiates (65-67 wt.\% $\mathrm{SiO}_{2}, 30 \% \mathrm{Mg \# )}$ requires three times the volume of cumulates. However, no pyroxenites (melanogabbro) in amounts equal to or exceeding that of lavas do exist at base of island arcs (Kelemen et al., 2004), which is an argument against the role of high-Al basalt presumed to be the parent magma for andesites and all island arc volcanics. Otherwise, one would have to invoke delamination, i.e., subduction of lower crust and its recycling together with eclogite (Kelemen et al., 2004; Sobolev et al., 2006). The primitive andesite composition (65 wt. $\% \mathrm{SiO}_{2}$ and $40 \% \mathrm{Mg \#}$ ) is closer to felsic rocks (70-75 wt.\% $\mathrm{SiO}_{2}, 30 \% \mathrm{Mg}$ ) than to pyroxenite cumulates. In this case, formation of andesite, dacite, and rhyolite requires three times less cumulates than felsic lavas, judging by experimental results.

The $\mathrm{Mg} \#$ vs. $\mathrm{SiO}_{2}$ plots in Fig. 14, C show two fractionation paths of primitive basalts or andesites, for the case the Aleutian arc. The case of Kamchatka is more complicated and we discuss it below with the examples of Klyuchevskoy and Bezymyanny volcanoes.

The material erupted from Klyuchevskoy and Bezymyanny has different compositions: it varies from magnesian to high-Al basalts in the former and from andesite to dacite in the latter. The variations in time, for Klyuchevskaya Sopka, have been as follows. Prior to 1945 the contents were (in wt.\%): 51-52 $\mathrm{SiO}_{2}, \sim 0.6 \mathrm{~K}_{2} \mathrm{O}, 0.8 \mathrm{TiO}_{2}$, and 45-55\% $\mathrm{Mg \#}$ $(\mathrm{FeO} / \mathrm{MgO}=0.8-1.2)$. Since the eruption of $1945 \mathrm{SiO}_{2}$ has increased to 54-55 wt.\% and has remained at this level till present; $\mathrm{K}_{2} \mathrm{O}$ has grown to $1-1.2 \mathrm{wt} \%, \mathrm{TiO}_{2}$ has reached 1-1.2 wt.\%, while Mg\# fell to below 40\%, i.e., $\mathrm{FeO} / \mathrm{MgO}=1.5-2.0$ (Fig. 15). Note that Klyuchevskoy is among the world most active volcanoes, with biennial eruptions, most often from the top crater, whereby the cone is progressively growing (it was $4850 \mathrm{~m}$ high in 2009 and currently approaches $5000 \mathrm{~m}$ ).

Bezymyanny underwent a paroxysmal eruption in 19551956, the first one after a long lull (Bogoyavlenskaya et al., 1991). The edifice became $200 \mathrm{~m}$ lower (currently $2882 \mathrm{~m}$ ) as a result of a lateral explosion and partial cone collapse. After the Pelean-type eruption, a new cone (Novyi) began growing inside the collapse crater. The activity before 1977 was associated with extrusion of a rigid obelisk-shaped block; later viscous lava flows were squeezed out as well, with the lavas becoming ever less viscous and the flows ever longer correspondingly. This change was related with changes in composition: $\mathrm{SiO}_{2}$ has deceased gradually from 61 wt. $\%$ (proximal to primitive andesite) in 1955 to $56 \mathrm{wt} . \%$ at present; $\mathrm{K}_{2} \mathrm{O}$ decreased slightly, over the same period, from 1.3 to 1.1 wt. $\%$, while $\mathrm{TiO}_{2}$ increased from 0.55 to 0.8 wt. $\%$; $\mathrm{Mg \#}$ $(\mathrm{FeO} / \mathrm{MgO}=1.5-2.5)$ has reduced from 40 to $30-35 \%$ and currently holds at this level.

Note that although the erupted material from the two volcanoes became progressively more proximal in major-element chemistry for the past 50 years, the trace-element compositions remain different. However, some trace elements 


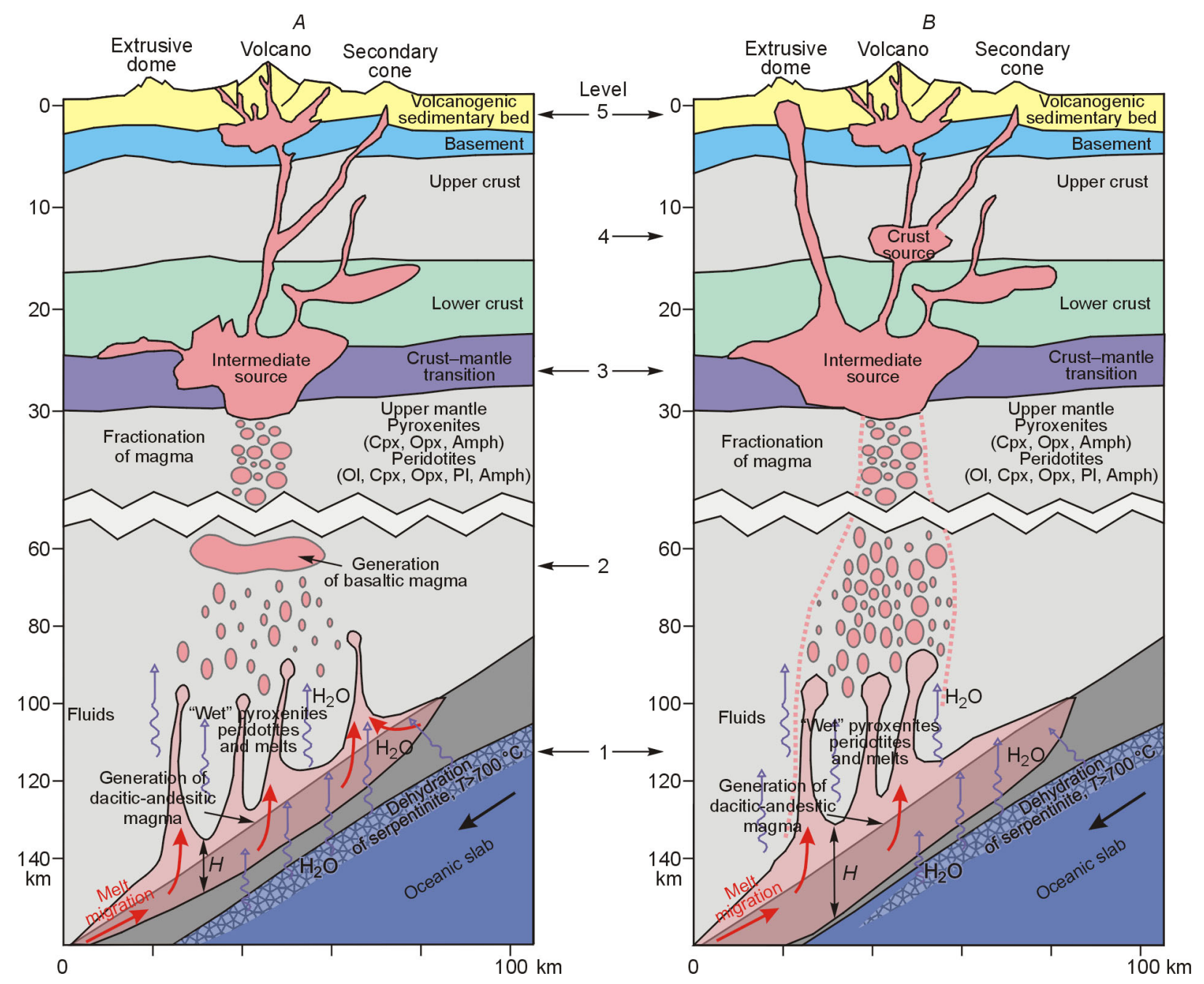

Fig. 12. Migration of fluids and melts in andesitic volcanoes of two types. $A$ : type I, tholeiitic volcanoes with mainly basaltic brief eruptions; $B$ : type II, calc-alkaline volcanoes, corresponding to activity peaks with voluminous explosive eruptions of dacitc-andesitic lavas. See five levels of magma generation and reactions, modified after (Ivanov, 2008).

likewise show a converging trend, such as Th which has increased almost twice since 1945 (to $0.7-0.8$ ppm in Klyuchevskoy and 1-1.2 ppm in Bezymyanny), or gradually equalizing $\mathrm{Rb} / \mathrm{Sr}$ and $\mathrm{Ba} / \mathrm{Sr}$ ratios, etc. (see below).

On the other hand, tephrochronology for a longer time span (Auer et al., 2008) indicates considerable composition changes in Klyuchevskoy, which ejected mostly high-Al material since 8500 years ago and then high-Mg basalts in some 2500 years. The transition to high-Mg basalts was more rapid (for 800-1000 years) than the decrease in $\mathrm{Mg}$ (and concurrent increase in $\mathrm{Al}$ ) which took about 2000 years. Bezymyanny formed about 5500 years ago during a stage of Mg\# decrease in Klyuchevskoy. The following peaks of explosive activity in Bezymyanny likewise fell at the stages of transition from high-Mg to high-Al basalts (2400-1700, 1350-1000 years BP, and since 1955).

Seismic tomography indicates that there may exist an intermediate reservoir shared by the two volcanoes at level 3 (crust-mantle transition, Fig. 12) which supplies compositionally similar melts (or fractionates of the same melt). The existence of a single magma source is consistent with isotope ratios of ${ }^{87} \mathrm{Sr} /{ }^{86} \mathrm{Sr}=0.7034-0.7035$ and ${ }^{143} \mathrm{Nd} /{ }^{144} \mathrm{Nd}=0.5131$ (Turner et al., 2007). The difference between the volcanoes is that melts rise directly to the surface during eruptions of Bezymyanny but stay in intermediate sources (levels 4 and 5) beneath Klyuchevskoy. Ariskin et al. (1995) were among the first to suggest this scenario. If the erupting lavas rise from the same source, those of Klyuchevskoy should be expected to experience greater fractionation and evolve toward higher $\mathrm{SiO}_{2}$ and alkalis but lower $\mathrm{Mg}$ contents. Fractional crystallization at the $30 \mathrm{~km}$ level leads to systematic changes from high-Al to high-Mg basalts erupted by Klyuchevskoy. Basaltic melt forms finally in intermediate chambers at levels 4 and 5 and releases more smoothly via the central conduit of Klyuchevskoy. Explosive eruptions of Bezymyanny, on the contrary, are due to high contents of volatiles accumulated at level 1, and to direct breakthrough from the subduction zone up to the surface, while interaction with the intermediate source at $30 \mathrm{~km}$ is only partial (Fig. 10B). 

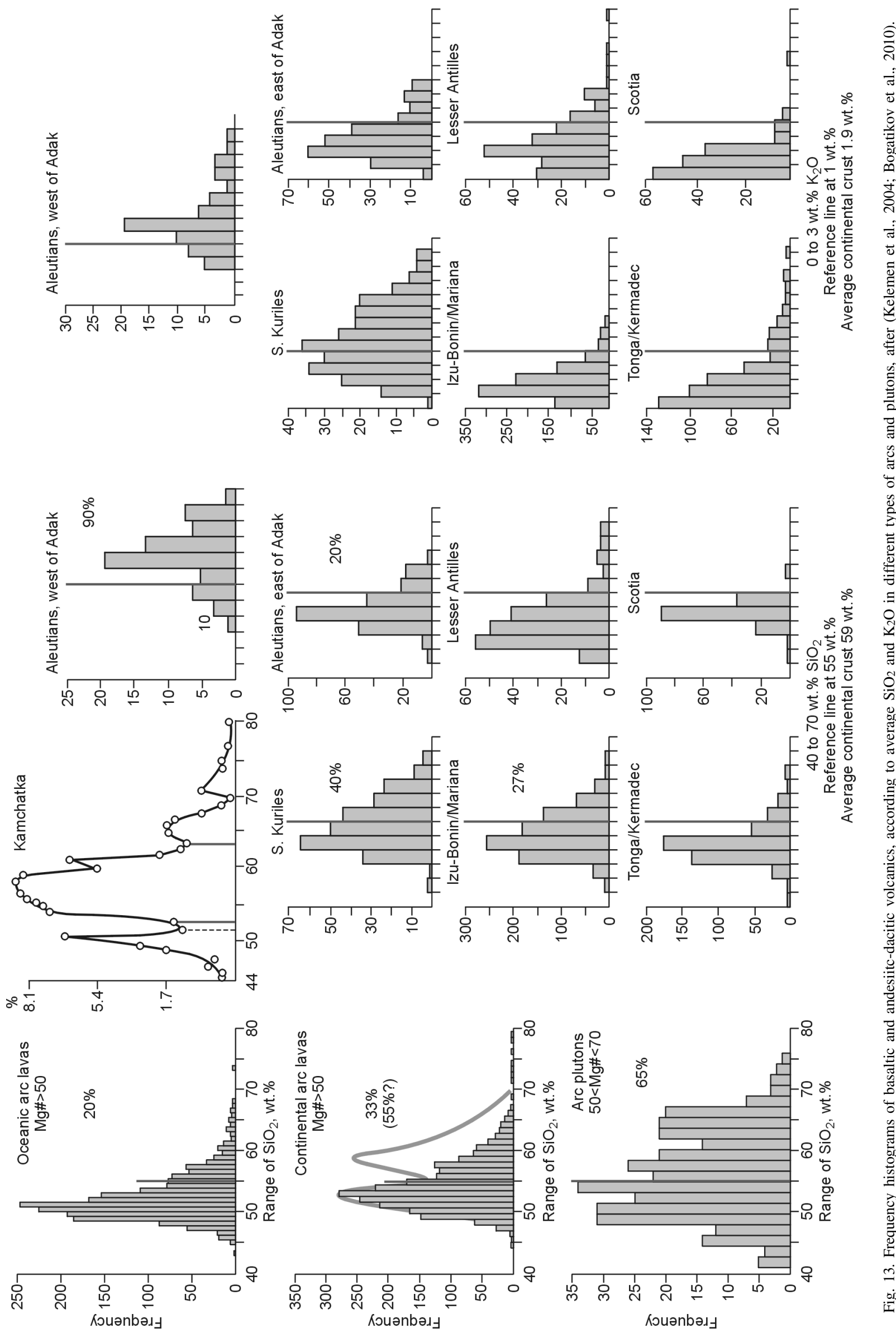
$A$

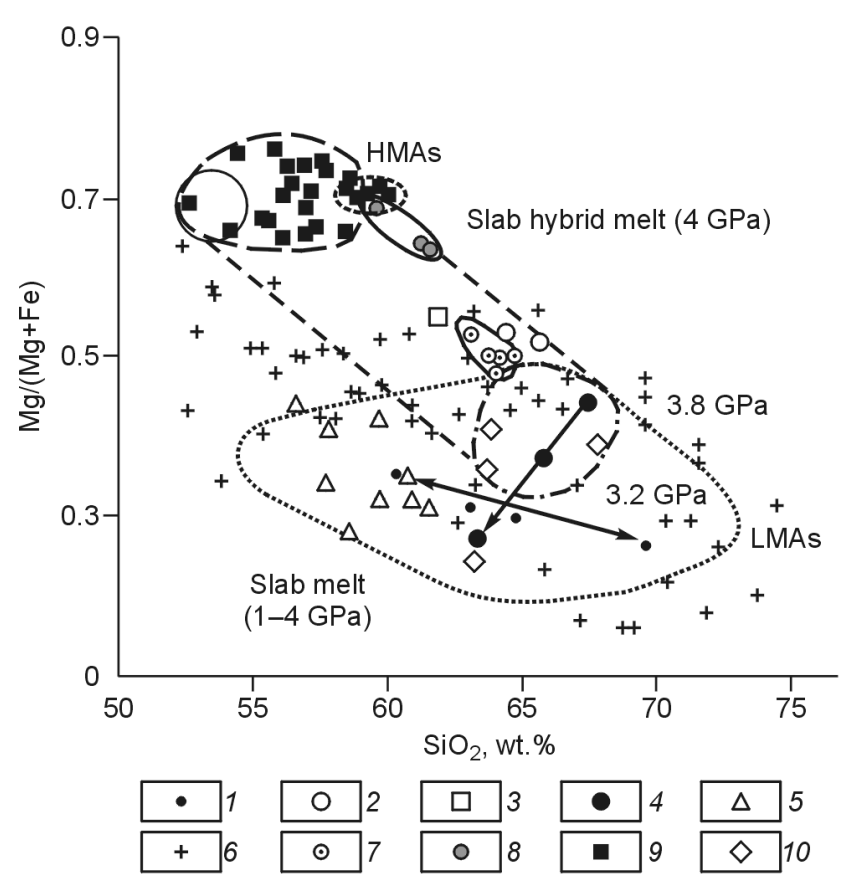

$B$

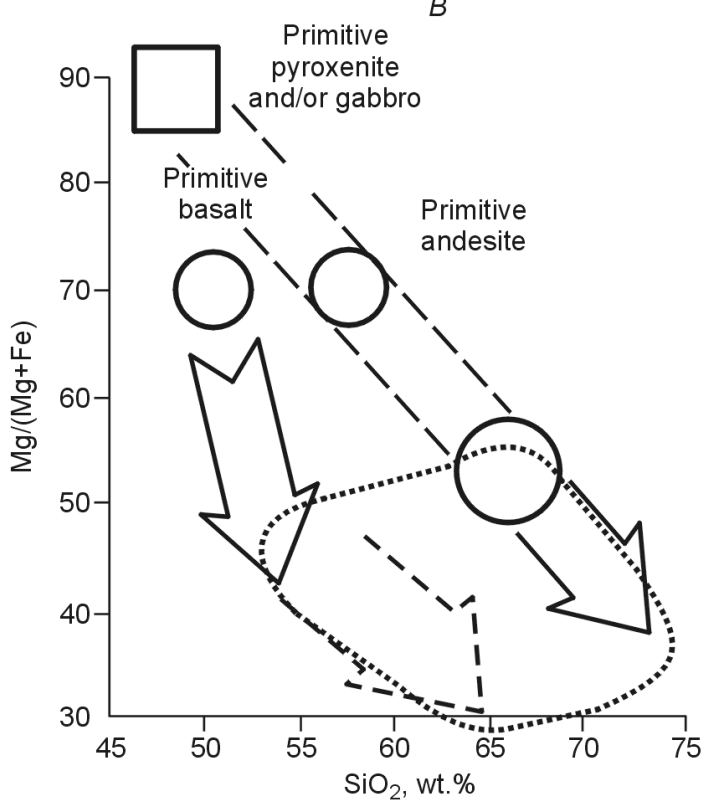

C

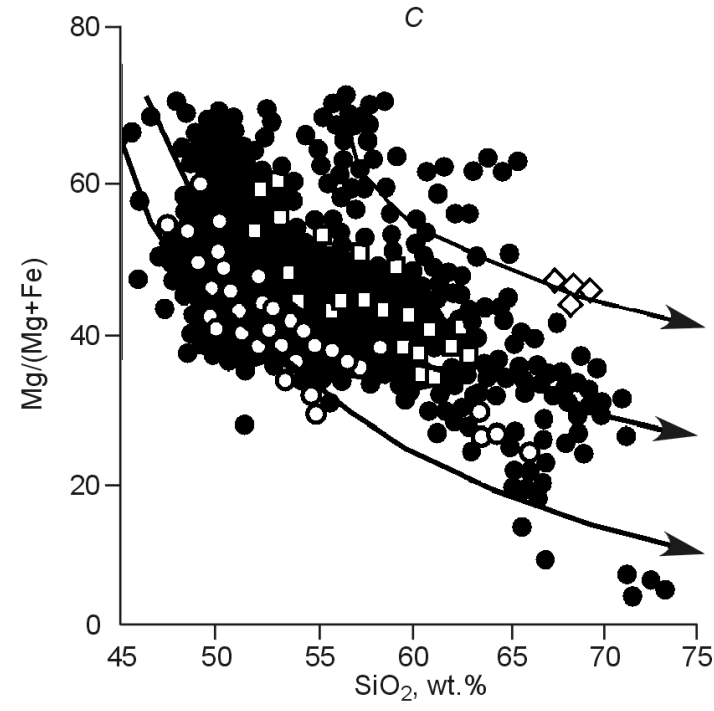

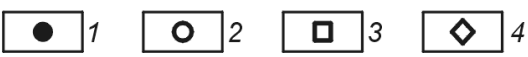

Fig. 14. A: Experimental data: fields of low-Mg basaltic andesite (LMAs) and high-Mg adakite and basaltic andesite (HMAs); $B$ : theoretical fields of primitive basalt and andesite compared with differentiates and cumulates as pyroxenite (or melanogabbro) stacked in a chamber at $30 \mathrm{~km}$; $C$ : differentiation paths of primitive basalt or andesite, with example from Aleutian arc. Arrows in A show possible fractionation trends, modified after (Dobretsov, 2010). 1, partial melting AV-1 (1-3 GPa); 2, melt AV-1, hybrid KLB-1; 3, melt AV-1, hybrid AVX-51; 4, melt AV-1 at 3.2 and $3.8 \mathrm{GPa}$; 5, melt inclusions in island arcs; 6, adakite of present island arcs; 7, low-Mg adakite of Southern Andes; 8, high-Mg adakite of Southern Andes; 9, magnesian adakite of Setoachi, Southeastern Japan; 10, adakite veins in peridotite of Northern Kamchatka. C: 1, all data; 2-4, data from Okmok (2), Seguam (3), and Piip (4) volcanoes. B and C are modified after (Kelemen et al., 2004).

Meanwhile, brief variations may be quite significant as evidence of complexity of processes going on in the long-lasting magma chamber at $30 \mathrm{~km}$. For instance, Ivanov (2008) cites the example of Karymsky which underwent fifteen eruption events between 1963 and 1978 while the compositions of its lavas changed alternately towards higher (e.g., 58.5 to 64 wt.\%) $\mathrm{SiO}_{2}$ and back (Fig. 16). During events 3 and 4, the $\mathrm{FeO} / \mathrm{MgO}$ ratios changed abruptly (first decreased to 2.1 and then grew rapidly to 3.8) while $\mathrm{SiO}_{2}$ averaged about 61 wt.\%. Similar FeO/MgO changes occurred during events 8 through 10 as the melt evolved from felsic to mafic compositions; the later lavas were in the calc-alkaline field while the melt evolution reversed from mafic to felsic in events 14 and 15 (over 60 wt.\% $\mathrm{SiO}_{2}$ and $\mathrm{FeO} / \mathrm{MgO}>3.0$ ). The main crystallization fields were calc-alkaline andesites with 60-62 wt.\% $\mathrm{SiO}_{2}$ and $\mathrm{FeO} / \mathrm{MgO}$ about 2 (events 3, 10-13, altogether 5 points, Fig. 16) and dacites with 6264 wt.\% $\mathrm{SiO}_{2}$ and $\mathrm{FeO} / \mathrm{MgO}$ about 3, near the boundary of the calc-alkaline field (events $5-8$ and 14,$15 ; 6$ points in Fig. 16). The variations of $\mathrm{FeO} / \mathrm{MgO}$ from 2 to 3.8 ( $\mathrm{Mg \#}$ from 34 to $26 \%$ ) at almost invariable $\mathrm{SiO}_{2}$ (60-62 wt.\%) may result from accumulation of orthopyroxene with about $30 \%$ Fe\#, and 

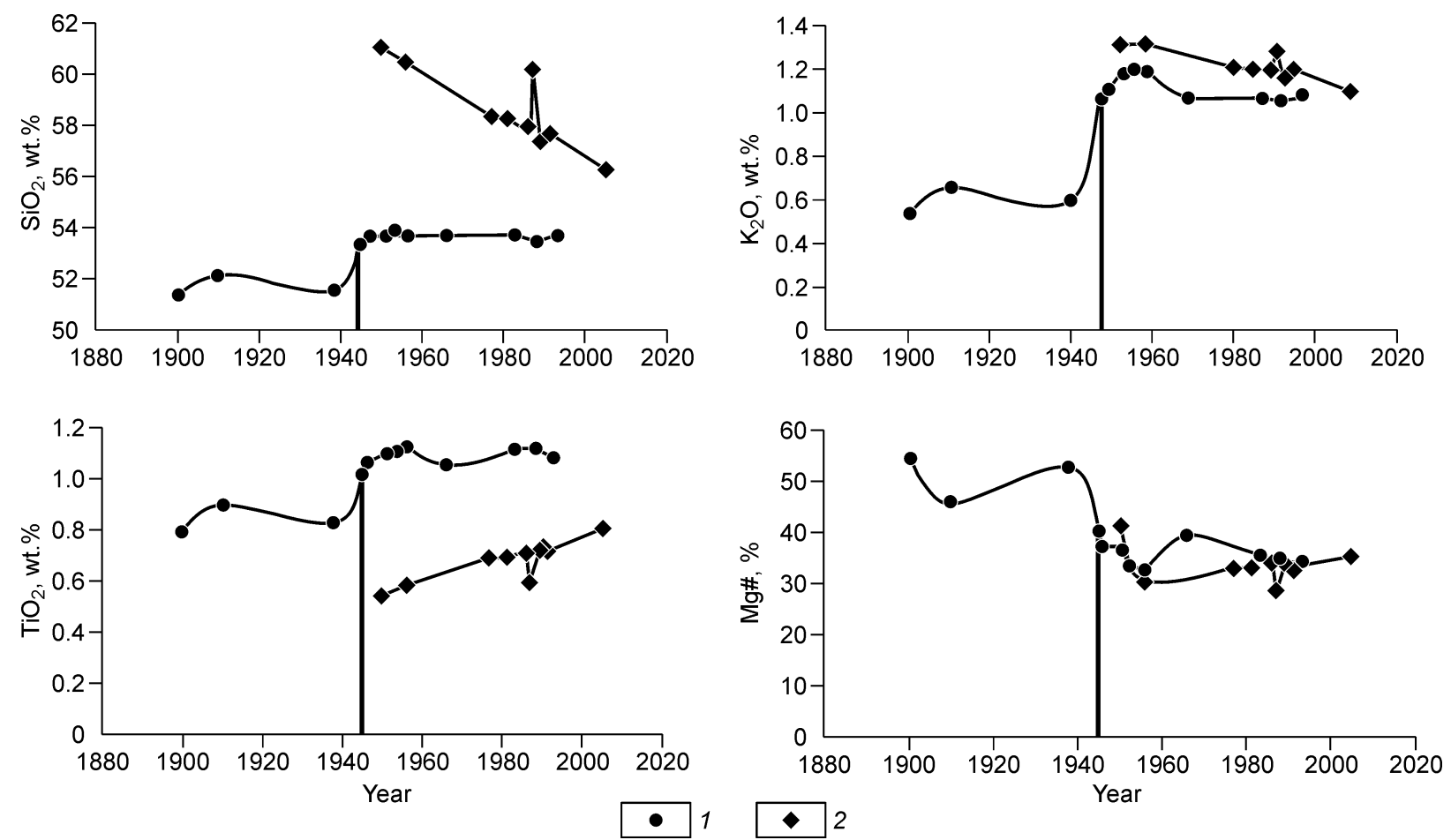

Fig. 15. Changes in major-oxide compositions of lavas in Klyuchevskoy (1) and Bezymyanny (2) volcanoes for past 100 years. Heavy bars mark Klyuchevskoy eruption event of 1945 after which lava compositions changed dramatically. This happened before a paroxysmal eruption of Bezymyanny after a long lull (Turner et al., 2007).

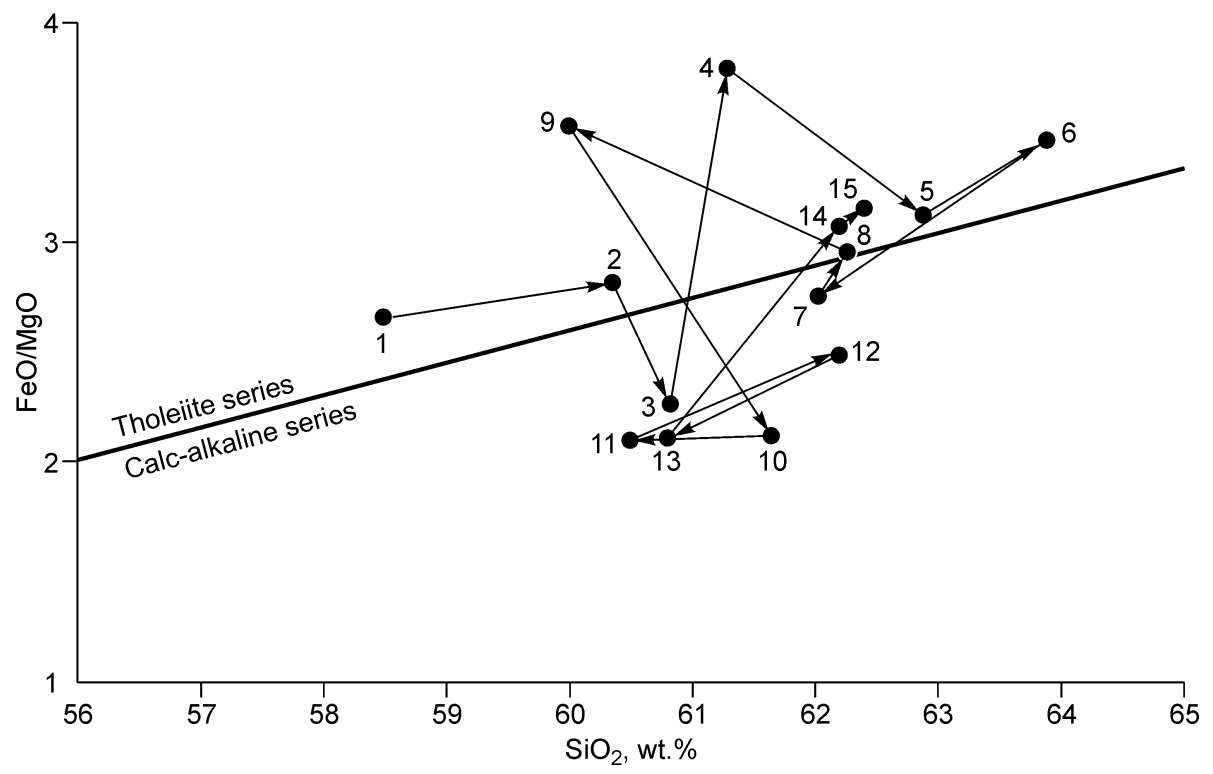

Fig. 16. Changes in lava compositions in Karymsky volcano from 1963 through 1978. Numerals from 1-15 are eruption phases, after (Ivanov, 2008).

with minor titanomagnetite. These magnetite-orthopyroxene nodules (cumulates) in lavas of Karymsky and other volcanoes in Kamchatka were reported in many publications (Erlikh, 1973; Ivanov, 2008).

Classification of the Kamchatka volcanics according to $\mathrm{FeO} / \mathrm{MgO}$ and $\mathrm{SiO}_{2}$, and their division into tholeiitic (high-Fe) and calc-alkaline (high-Mg) series is shown in Fig. 17.
Shiveluch, a typically calc-alkaline-type volcano, repeatedly erupts a continuous series of lavas with $\mathrm{SiO}_{2}$ growing from 52 to 69 wt.\% at constant $\mathrm{FeO} / \mathrm{MgO}=1.0-2.0$ (Mg\# about $45 \%)$. Bezymyanny ejects mainly calc-alkaline andesitic and dacitic lavas with $\mathrm{SiO}_{2}$ from 54 to 67 wt.\% and a minor increase in $\mathrm{FeO} / \mathrm{MgO}$ from 1.0 to 2.5 . Only a small part of andesites in Bezymyanny (about 12\%) may be classified as 

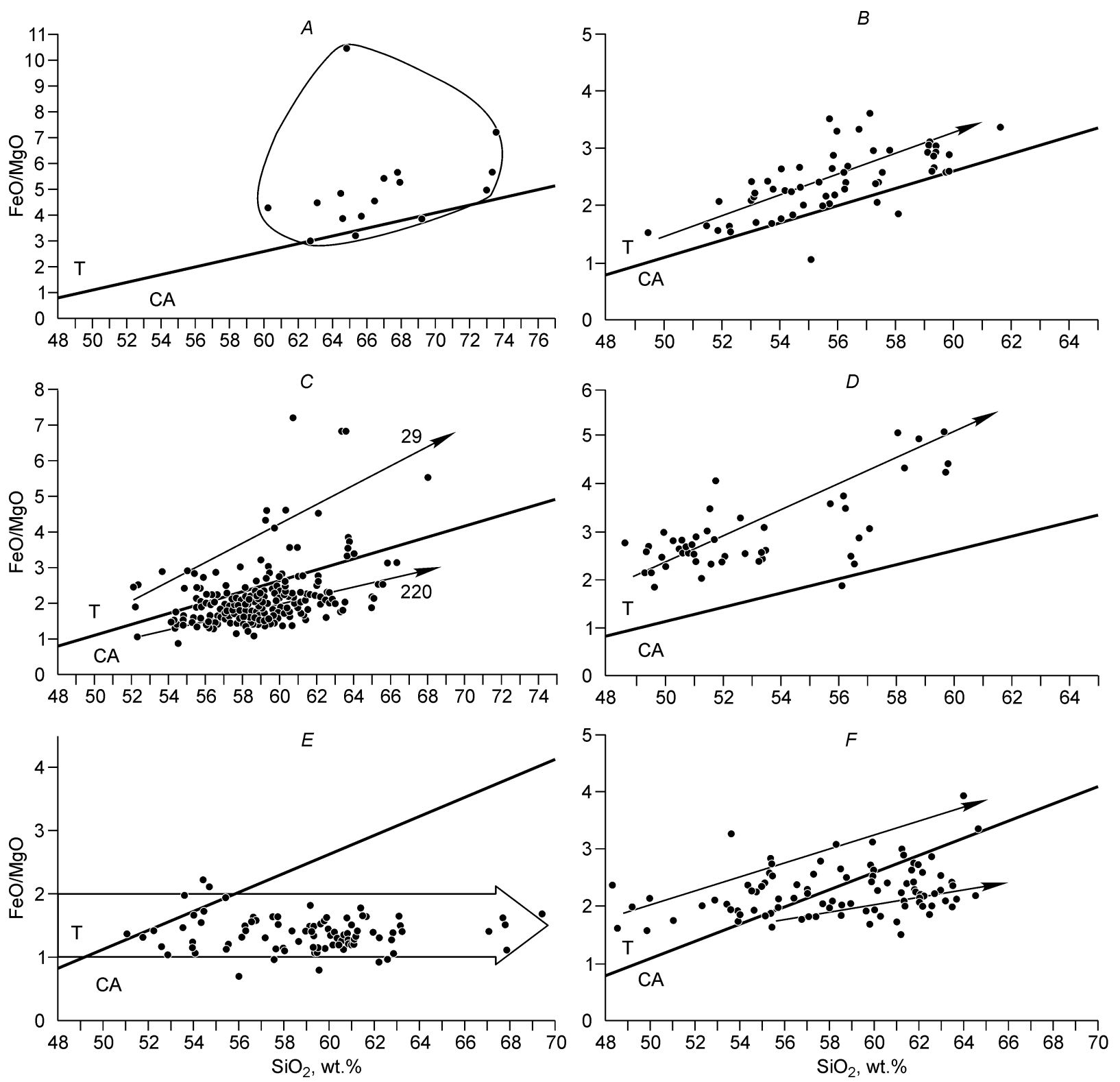

Fig. 17. Kamchatka lavas in $\mathrm{FeO} / \mathrm{MgO}-\mathrm{SiO}_{2}$ diagram. Solid line divides fields of tholeiitic (T) and calc-alkaline (CA) compositions. A, Ignimbrite of Karymsky ring structure; $B$, Ushkovsky and Krestovsky; $C$, Bezymyanny; $D$, Kizimenok; $E$, Shiveluch; $F$, Kizimen, after (Ivanov, 2008).

tholeiitic with $\mathrm{FeO} / \mathrm{MgO}$ growing from 2.0 to 6.5. Kizimen volcano consists of approximately equal amounts of calc-alkaline (mainly andesite with $56-64 \mathrm{wt} . \% \mathrm{SiO}_{2}$ ) and tholeiitic rocks (half of them are basalts with $48-55$ wt. $\% \mathrm{SiO}_{2}$ and the other half are andesites with 56-64 wt.\% $\mathrm{SiO}_{2}$ ). Ignimbrites of Karymsky caldera contain $61-74$ wt. $\% \mathrm{SiO}_{2}$ and plot near the boundary between the tholeiitic and calc-alkaline fields, as well as the Karymsky most felsic rocks (Fig. 16).

Typical tholeiitic lavas of Kizimenok, Ushkovsky, and Krestovsky (Fig. 17) contain 49-60 wt.\% $\mathrm{SiO}_{2}$, while basalts predominate only in the products of Kizimenok.

In conclusion, we cite some statistics of volcanic hazard monitoring in the Kuriles (Ermakov et al., 2011). Altogether more than 120 eruptions, with peaks at every 40-50 years, have occurred in the Kuriles arc from 1700 to 2000. Volcan- ism culminated in the latest $20^{\text {th }}$ century when about 30 eruptions happened in 20 years and the geography of eruptions broadened considerably. Most of events were restricted to the Central Kuriles before the middle of the $19^{\text {th }}$ century but the activity spread to the Northern Kuriles in the end of the century and to the Southern Kuriles a century later (Ermakov et al., 2011).

\section{Mineralogy and chemistry of island arc lavas}

In this paper we confine ourselves to only a brief synopsis of mineralogy and chemical compositions of island arc volcanic rocks, with a focus on three key points, namely, (i) implications for water content and oxygen fugacity of melts; 


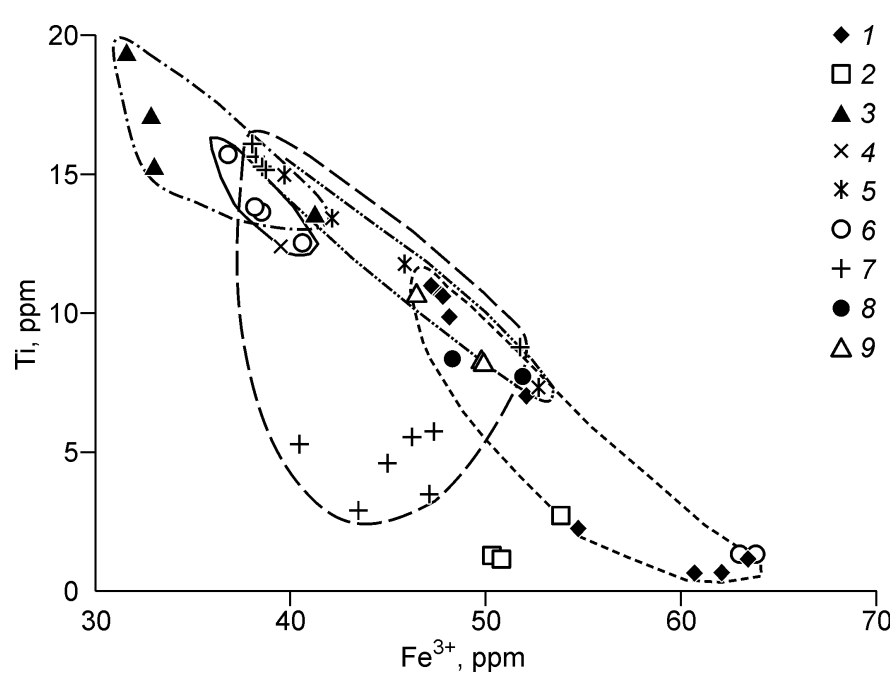

Fig. 18. Compositions of spinels in Kamchatka lavas. Compiled by Dobretsov based on analyses reported in (Ivanov, 2008). 1-9, volcanoes: Shiveluch (1), Ushkovsky (2), Klyuchevskoy (3), Bezymyanny (4), Kizimen (5), Dvor (6), Karymsky (7), a new eruption center (Tokarev crater) (8), Ichinsky (9).

(ii) role of supercritical liquid below $150 \mathrm{~km}$ (introduction into the problem); (iii) minor and trace elements as a record of crystallization history and temperature of fluid release (some examples).

Island arc magmas are known to contain much water and oxygen but the estimates of their contents are often controversial and poorly consistent with the composition of volcanism. One may assume, in the first approximation, that adakite (hornblende andesite) is an indicator of highly hydrous melts, two-pyroxene andesite represents dry melts, and hornblendepyroxene andesite is intermediate in this respect; titanomagnetite and orthopyroxene are more precise mineral tracers of water contents and oxidation degrees.

Aqueous fluids liberate from the slab at all stages of subduction and control oxygen fugacity at the QMF (quartzmagnetite-fayalite) and MW (magnetite-wüstite) buffers. Minerals that concentrate water in oceanic crust are: serpentine (in olivine rocks), chlorite, pumpelliyte, epidote, actinolite, sometimes lawsonite (in metamorphic basalts), and chlorite, phengite, stilpnomelane, and amphibole (in sediments and metamorphic sediments). Oceanic and forearc-basin sediments are commonly highly oxidized and very rarely contain bitumen and carbonaceous material (oxygen fugacity in these local zones may differ strongly from that in the surroundings). At small melting degrees, melts that arise in subduction zones are fully saturated with water, while the potential of water $\left(\mathrm{H}_{2} \mathrm{O}\right.$ content in the first approximation) decreases at larger melt fractions. Further dehydration and reduction of the melt are expected to occur at level $2(50-70 \mathrm{~km})$ on reaction with hot dry mantle where magnetite may disappear, as well as at level 3, about $30 \mathrm{~km}$ (Fig. 12), where a part of fluids liberate and escape, while the ambient lower crust may be relatively dry.

Hornblende phenocrysts, as well as fluid-melt inclusions in amphibole and plagioclase, provide direct evidence of high

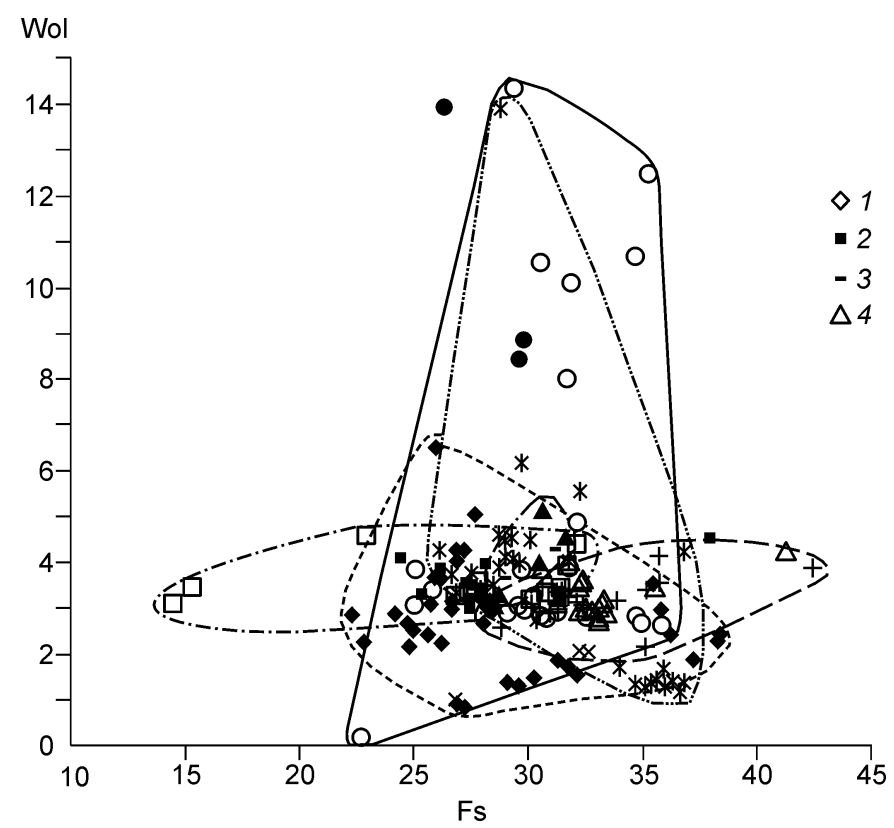

Fig. 19. Orthopyroxenes in Kamchatka lavas in ferrosilite (Fs), wollastonite (Wol) diagram. Compiled by Dobretsov based on analyses reported in (Ivanov, 2008). 1-4, volcanoes: Kamen' (1), Kizimenok (2), Malyi Semyachik (3), Akademii Nauk (4). Other symbols are as in Fig. 18.

water contents in melts, whichever be their compositional diversity. Hydrous melts have high $f_{\mathrm{H}_{2} \mathrm{O}}$ and $f_{\mathrm{O}_{2}}$, while titanomagnetite with 7-16 wt.\% $\mathrm{TiO}_{2}$ crystallizes at the liquidus (Fig. 18). Some lavas (specifically, from Karymsky volcano) bear titanomagnetite with $\mathrm{Al}_{2} \mathrm{O}_{3}$ as high as 5-7 wt.\% (a spinel-hercynite component $\left.(\mathrm{Fe}, \mathrm{Mg}) \mathrm{Al}_{2} \mathrm{O}_{4}\right)$, which confirms its crystallization at the liquidus. Titanomagnetite with lower $\mathrm{TiO}_{2}$ (3-6 wt.\%) crystallizes together with orthopyroxene. Early titanomagnetite precipitates commonly at level 3, or about $30 \mathrm{~km}$ (Fig. 12).

The residual melt after the early precipitation of titanomagnetite becomes depleted in Fe and Ti (Fig. 16, 17), and the $\mathrm{FeO} / \mathrm{MgO}$ ratios decrease from 3.8 to 2.1 while $\mathrm{SiO}_{2}$ remains invariable. Note that low $\mathrm{FeO} / \mathrm{MgO}(1.0-2.5)$ and $\mathrm{TiO}_{2}$ (0.6-0.7 wt.\%) hold in the whole series of lavas in such volcanoes as Bezymyanny and Shiveluch (Fig. 17), but low-Fe silicates (orthopyroxene and hornblende in andesite and olivine in basalt) crystallize in the residual melt. Orthopyroxenes can be tentatively divided into several groups (Fig. 19): (i) those with Fe\# in the range 22-26\% and high $\mathrm{Ca}$ contents (up to $15 \%$ wollastonite, liquidus-free crystallization) crystallize from most highly oxidized and hydrous melts; (ii) intermediate orthopyroxenes have 27-34\% Fe\# and are likewise high in $\mathrm{Ca}$; (iii) those with Fe\# as high as 34-41\% and low wollastonite percentages (to 5\%) crystallize from low- $\mathrm{H}_{2} \mathrm{O}$ reduced melts far from the liquidus. Island-arc boninite magmas produced by reactions of fluids/melts with mantle at the depths $50-80 \mathrm{~km}$ have the most reduced compositions (at still high $\mathrm{H}_{2} \mathrm{O}$ ), while Fe\# in late pyroxenes 

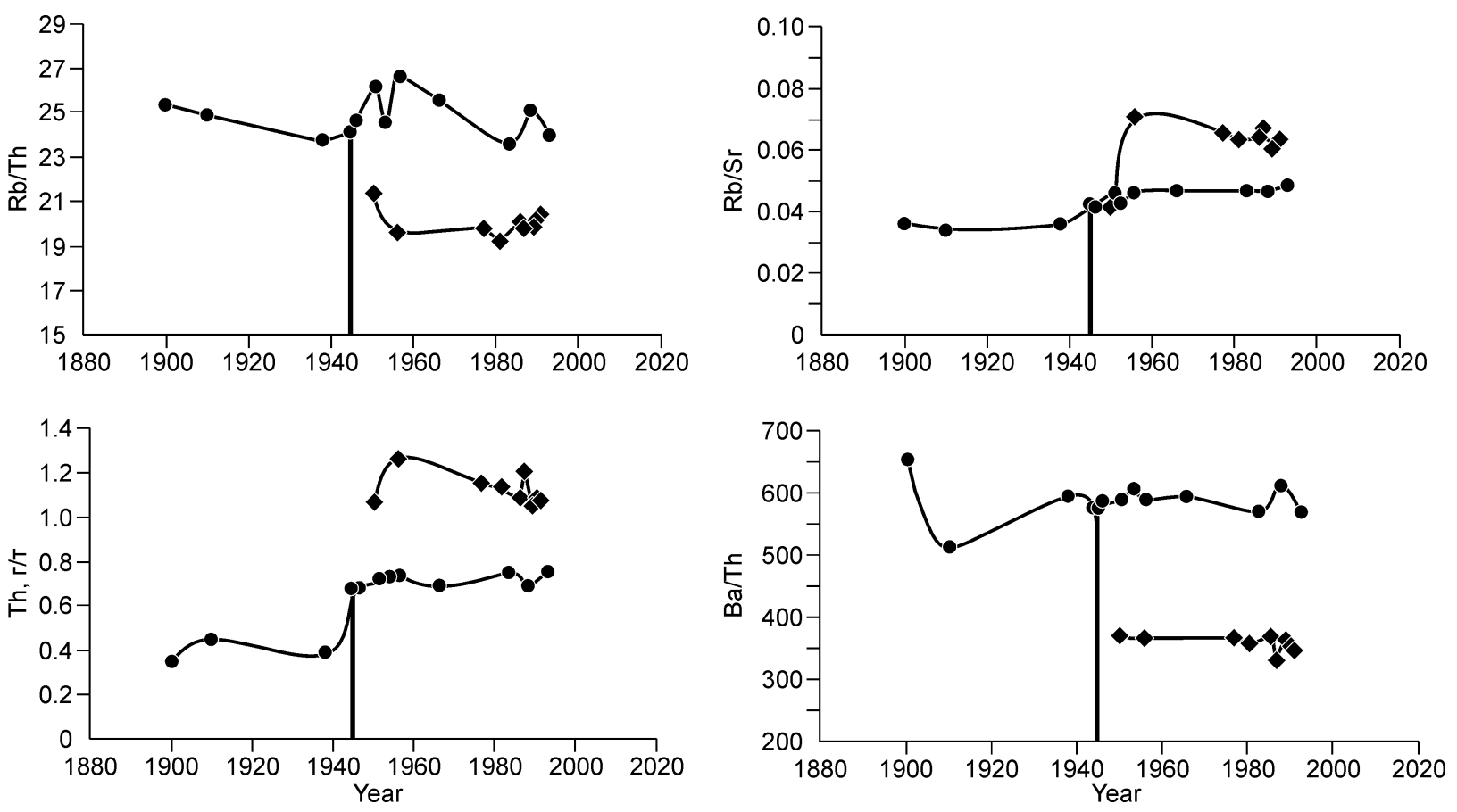

Fig. 20. Changes in trace-element compositions of lavas in Klyuchevskoy (1) and Bezymyanny (2) volcanoes for past 100 years. Legend same as in Fig. 15.

and amphiboles may reach 60-65\% (Danyushevsky et al., 2002; Dobretsov, 2010).

Rutile, garnet, and plagioclase concentrate other major elements at different levels of magma generation and reactions. Rutile is present in eclogite only, and the melt forming in the subduction zone is depleted in $\mathrm{Nb}$ and $\mathrm{Ta}$ which remain in rutile of the residual melt. The relative abundances of Ti-Nb-Ta may change only on crystallization of ilmenite at levels 2 and 3 (Fig. 12). Garnet should be present at level 1, or sometimes at level 2, and is the principal concentrator of heavy REE. The REE patterns remain steep $(\mathrm{La} / \mathrm{Yb}>10)$ only in melts that penetrate directly from the subduction zone, but are flat when the melts react with mantle at level 2. The latter scenario likely applies to the Kamchatka volcanics judging by their low-angle slope of REE curves (Ivanov, 2008). Accumulation of plagioclase in the intermediate reservoir at level 3 may cause marked changes in $\mathrm{REE}, \mathrm{Sr}, \mathrm{Ba}$, and $\mathrm{Rb}$ abundances (Fig. 12). Note especially high $\mathrm{Sr}$ in all Kamchatka lavas.

According to experiments of Kessel et al. (2005), a fluid enriched in rock-forming components should exist in the zone of melting below $950{ }^{\circ} \mathrm{C}$ at pressures about $6 \mathrm{GPa}$, a melt with high contents of volatiles appears above $950{ }^{\circ} \mathrm{C}$, and only melt is present, even at high temperatures, at $4 \mathrm{GPa}$; traceelement ratios presumably have implications for melting conditions. However, these experiments are not very helpful in practice because they take no account of changes the fluids and melts undergo on their way to the surface and in magma sources. Nevertheless, even being not very consistent with experimental evidence, the trace-element compositions of the Klyuchevskoy and Bezymyanny volcanics (Th, Th/Rb, Rb/Sr) change correspondingly to the major-element changes (Fig. 20). An example of a satisfactory fit between the experimental and natural compositions is given in Fig. 21. The $\mathrm{Th} / \mathrm{Rb}$ ratio is one of few experimental parameters that decrease systematically on temperature decrease, be it a melt (at 4 and $6 \mathrm{GPa}$ ) or a hot supercritical liquid (at $6 \mathrm{GPa}$ ). Note that a single analysis (Odnobokiy volcano) shows a value proximal to real temperatures in the melting zone. If the experimental data are correct (Kessel et al., 2005), the colder temperatures imprinted in trace-element compositions of the Kamchatka lavas reflect different phases of reactions between still hot rocks and late fluids.

\section{Conclusions}

Regional tomographic models of the upper mantle beneath the Kuriles-Kamchatka and Aleutian arcs image a complex and heterogeneous structure of the subduction system. The slab geometry and thickness variations are typical of subduction depths to 200-300 km. At greater depths, the behavior of slabs changes being controlled by melting degrees and by the driving forces they are subject to.

Local tomography images of lithosphere beneath volcanoes of the Klyuchevskoy group reveal a large magma reservoir (a conduit and an intermediate chamber) with anomalously low seismic velocities at the crust-mantle boundary, while the feeding material comes from the boundary between the slab and the mantle wedge. Two low-velocity zones in the crust indicate the existence of intermediate sources at 12-15 and $0-5 \mathrm{~km}$. 


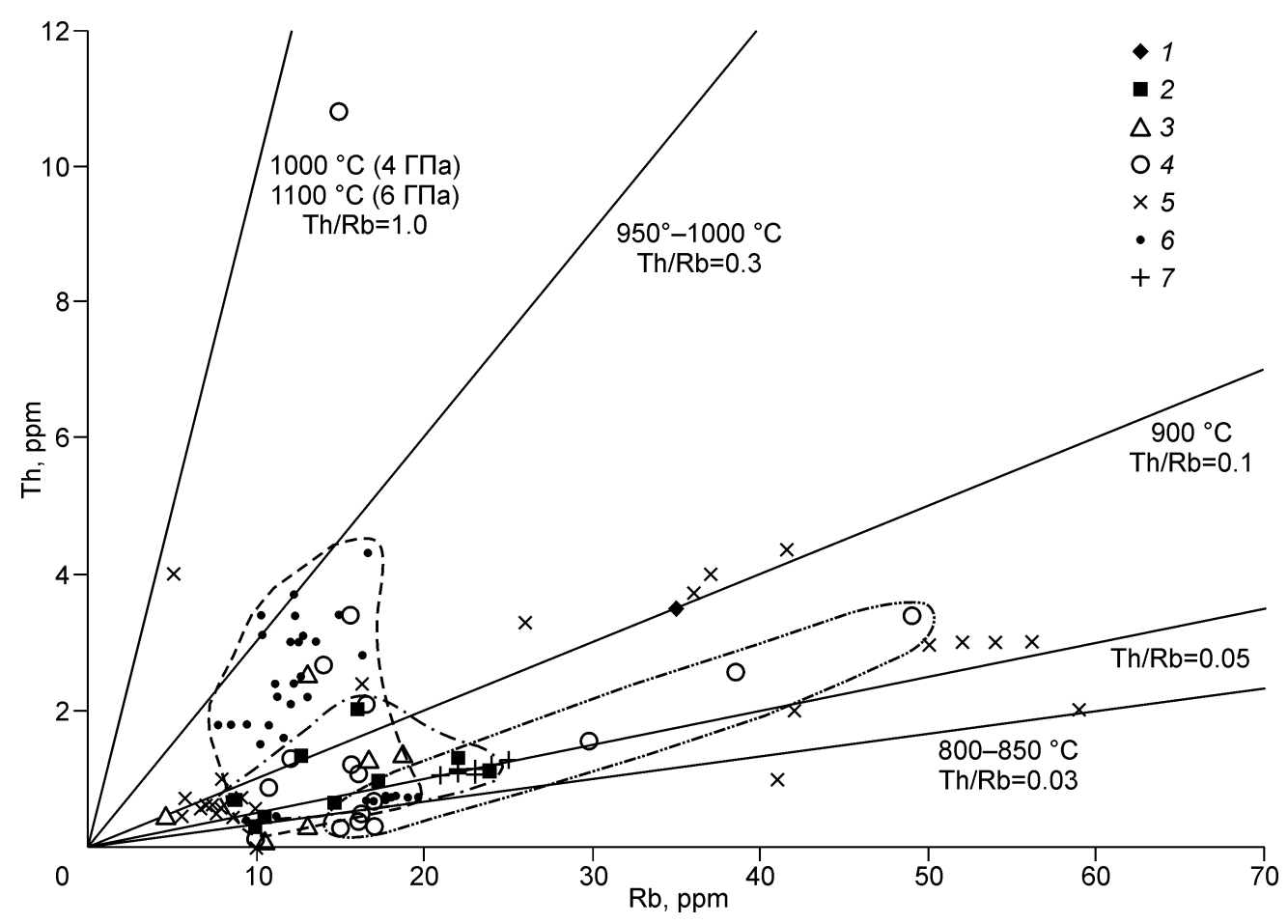

Fig. 21. Experimental and natural compositions of lavas in Th-Rb diagram, for Karymsky group of volcanoes. 1-7, volcanoes: paleo-Karymsky (1), Zhupanovskie Vostryaki (2), Belyankina (3), Odnobokiy (4), a new eruption center (Tokarev crater) (5), Klyuchevskoy (6), Bezymyanny (7). Temperatures next to Th/Rb curves are experimental values for respective ratios, after (Kessel et al., 2005). Natural $\mathrm{Th} / \mathrm{Rb}$ ratios in lavas of Klyuchevskoy and Bezymyanny are given for comparison. Compiled by Dobretsov based on analyses reported in (Ivanov, 2008).

Generally, our modeling predicts magma generation and reactions at five depth levels: formation of $\mathrm{H}_{2} \mathrm{O}$-rich melts/fluids within the eclogite facies, at 100-120 km (level 1); reaction between the fluid-saturated melts (or enriched fluids) rising from level 1 with hot mantle peridotite at 50-70 km (level 2); melting in an intermediate zone at the crust base, where main AFC (assimilation and fractional crystallization) processes develop, at $25-30 \mathrm{~km}$ (level 3); melting in transitory intermediate chambers, at $12-15 \mathrm{~km}$, with possible crustal contamination of the molten material (level 4); melting in local zones immediately underneath volcanoes $(0-5 \mathrm{~km})$ right before eruptions (level 5).

Primitive andesites appear at level 1 when the melting zone is the thickest. In this case, they rise directly to level 3 skipping level 2 where they would react with the mantle otherwise, which may cause violent explosive eruptions. Melting of metasediments and metabasalts in thinner zones gives rise to relatively smooth volcanism, while andesitic and basaltic melts can react with mantle peridotite at level 2 .

Fractional crystallization of primitive basalts and andesites and their derivates occurs at levels 1 and 3 , being controlled by the oxidation degree (water content) and possible precipitation or, on the contrary, uptake of five minerals: garnet and/or rutile at level 1; reactions involving olivine at level 2; titanomagnetite, orthopyroxene, and plagioclase at level 3.

The paper profited much from constructive criticism by M.I. Kuz'min and A.E. Izokh. The study was carried out as part of Integration Project 20 of the Siberian Branch of the
Russian Academy of Sciences and project ESD-7.3 of the Russian Academy of Sciences (Department of Geosciences).

\section{References}

Ariskin, A.A., Barmina, G.S., Ozerov, A.Yu., Nilsen, R.L., 1995. Genesis of high-Al basalts of Klyuchevskoy volcano. Petrologiya 3 (5), 42-67.

Auer, S., Bindeman, I., Wallace, P., Ponomareva, V., Portnyagin, M., 2008. The origin of hydrous, high-ä ${ }^{18} \mathrm{O}$ voluminous volcanism: diverse oxygen isotope values and high magmatic water contents within the volcanic record of Klyuchevskoy volcano, Kamchatka, Russia. Contrib. Mineral. Petrol. 157 (2), 209-230.

Bogatikov, O.A., Kovalenko, V.I., Sharkov, E.V., 2010. Magmatism, Tectonics, and Geodynamics of the Earth: Links in Space and Time [in Russian]. Nauka, Moscow. (IGEM RAN Transactions, Issue 3).

Bogdanov, N.A., Dobretsov N.L., 2002. The Okhotsk volcanic oceanic plateau. Geologiya i Geofizika (Russian Geology and Geophysics) 43 (2), 101-114 (87-99).

Bogoyavlenskaya, G.E., Braitseva, O.A., Melekestsev, I.V., Maksimov, A.P., Ivanov, B.V., 1991. Bezymyanny volcano, in: Fedotov, S.A., Masurenkov, Yu.P. (Eds.), Active Volcanoes of Kamchatka [in Russian]. Book 1, Nauka, Moscow, pp. 168-200.

Danyushevsky, L.V., McNeil, A.W., Sobolev, A.V., 2002. Experimental and petrological studies of melt inclusions in phenocrysts from mantle-derived magmas: an overview of techniques, advantages and complications. Chem. Geol. 183, 5-24.

Dobretsov, N.L., 2010. Petrology, geochemistry, and geodynamics of subduction magmatism. Petrologiya, No. 1, 1-24.

Dobretsov, N.L., Kirdyashkin, A.G., 1997. Modeling of subduction processes. Geologiya i Geofizika (Russian Geology and Geophysics) 38 (5), 846-856 (884-895). 
Dobretsov, N.L., Kirdyashkin, A.G., Kirdyashkin, A.A., 2001. Deep-seated Geodynamics [in Russian]. $2^{\text {nd }}$ edition. Izd. SO RAN, Filial GEO, Novosibirsk.

Erlikh, E.N., 1973. The Present Structure and Quaternary Volcanism in the Western Circumpacific Area [in Russian]. Nauka, Novosibirsk.

Ermakov, V.A., Abdurakhmanov, A.I., Ermakov, A.V., Semakin, V.P., Shteinberg, G.S., 2011. Volcanic Zoning: Geological Background and Hazard Prediction (Example of Mendeleev Volcano, Kunashir Island) [in Russian]. Mordvintsev, Moscow.

Fedotov, S.A., Masurenkov, Yu.P. (Eds.), 1991. Active Volcanoes of Kamchatka [in Russian]. Nauka, Moscow, Book 1; Book 2.

International Seismological Centre, 2001. Bulletin Disks 1-9 (CD-ROM), Intern. Seismol. Cent., Thatcham, UK.

Ivanov, B.V., 2008. Andesites of Kamchatka [in Russian]. Nauka, Moscow. Izokh, A.E., Smirnov, S.Z., Egorova, V.V., Chang Tuan Anh, Kovyazin, S.V., Ngo Thi Phuong, Kalinina, V.V., 2010. The conditions of formation of sapphire and zircon in the areas of alkali-basaltoid volcanism in Central Vietnam. Russian Geology and Geophysics (Geologiya i Geofizika) 51 (7), 719-733 (925-943).

Johnson, M.C., Plank, T., 1999. Dehydration and melting experiments constrain the fate of subducted sediments. Geochim. Geophys. Geosyst. 1 (12), 1007, doi:10.1029/1999GC000014.

Kelemen, P.B., Hanghoj, K., Green, A.R., 2004. One view of the geochemistry of subduction-related magmatic arcs, with an emphasis on primitive andesite and lower crust, in: Holland, H.D., Turekian, K.K. (Eds.), Treatise on Geochemistry, Elsevier, Amsterdam, pp. 593-659.

Kepezhinskas, P., Defant, M.J., Widom, E., 2002. Abundance and distribution of PGE and $\mathrm{Au}$ in the island-arc mantle: implications for sub-arc metasomatism. Lithos 60, 113-128.

Kessel, R., Ulmer, P., Pettke, T., Schmidt, M.W., Thompson, A.B., 2005. The water-basalt system at 4-6 GPa: phase relations and second critical endpoint in a K-free eclogite at 700 to $1400{ }^{\circ} \mathrm{C}$. Earth Planet. Sci. Lett. 237, 873-892.

Koulakov, I., 2009. LOTOS code for local earthquake tomographic inversion. Benchmarks for testing tomographic algorithms. Bull. Seismol. Soc. Amer. 99 (1), 194-214, doi: 10.1785/0120080013.

Koulakov, I.Yu., Sobolev, S.V., 2006. A tomographic image of Indian lithosphere break-off beneath the Pamir Hindukush Region. Geophys. J. Int. 164, 425-440.

Koulakov I., Tychkov S., Bushenkova N., Vasilevskiy A., 2002. Structure and dynamics of the upper mantle beneath the Alpine-Himalayan orogenic belt from teleseismic tomography. Tectonophysics 358, 77-96.

Koulakov, I., Sobolev, S.V., Asch, G., 2006. P- and S-velocity images of the lithosphere-asthenosphere system in the Central Andes from local-source tomographic inversion. Geophys. J. Int. 167, 106-126.

Koulakov, I., Bohm, M., Asch, G., Lühr B.-G., Manzanares, A., Brotopuspito, K.S., Fauzi, P., Purbawinata, M.A., Puspito, N.T., Ratdomopurbo, A., Kopp, H., Rabbel, W., Shevkunova, E., 2007. P and S velocity structure of the crust and the upper mantle beneath central Java from local tomography inversion. J. Geophys. Res. 112, B08310, doi:10.1029/2006 JB004712.

Koulakov, I., Yudistira, T., Luehr, B.-G., Wandono, 2009a. $P, S$ velocity and $V_{P} / V_{S}$ ratio beneath the Toba caldera complex (Northern Sumatra) from local earthquake tomography. Geophys. J. Int. 177, 1121-1139, doi: 10.1111/j.1365-246X.2009.04114.x.

Koulakov, I., Jakovlev, A., Luehr, B.G., 2009b. Anisotropic structure beneath central Java from local earthquake tomography. Geochem. Geophys. Geosyst. 10, Q02011, doi: 10.1029/2008GC002109.
Koulakov, I.Yu., Dobretsov, N.L., Bushenkova, N.A., Yakovlev, A.V., 2011a. Slab shape in subduction zones beneath the Kuriles-Kamchatka and Aleutian arcs based on regional tomography. Russian Geology and Geophysics (Geologiya i Geofizika) 52 (6), 650-667 (830-851).

Koulakov, I., Gordeev E. I., Dobretsov, N.L., Vernikovsky, V.A., Senyukov, S., Jakovlev, A., 2011b. Feeding volcanoes of the Kluchevskoy group from the results of local earthquake tomography. Geophys. Res. Lett. 38, L09305, doi:10.1029/2011GL046957.

Koulakov, I., Gordeev, E.I., Dobretsov, N.L., Vernikovsky, V.A., Senyukov, S., Jakovlev, A., Jaxybulatov, K., 2012. Variable feeding regimes of the Kluchevskoy group volcanoes (Kamchatka, Russia) derived from time-dependent seismic tomography. J. Volcanol. Geotherm. Res.

Laverov, N.P., Bogatikov, O.A., Dobretsov, N.L., 2005. Late Cenozoic and Present Volcanism in the Territory of Russia [in Russian]. Nauka, Moscow.

Martin, H., Smithies, R.H., Rapp, R., Moyen, J.-F., Champion, D., 2005. An overview of adakite, tonalite-trondhjemite-granodiorite (TTG), and sanukitoid: relationships and some implications for crustal evolution. Lithos 79, $1-24$.

Masturyono, McCaffrey, R., Wark, D.A., Roecker, S.W., Fauzi, P., Ibrahim, G., Sukhyar, 2001. Distribution of magma beneath Toba Caldera, North Sumatra, Indonesia, constrained by 3-dimensional P-wave velocities, seismicity, and gravity data. Geochem. Geophys. Geosyst. 2 (4), doi:10.1029/2000GC000096.

Rapp, E.P., Watson, E.B., 1995. Dehydratation melting of metabasalt at 8-32 kbar: implications for continental growth and crustal-mantle recycling. J. Petrol. 36, 891-931.

Singer, B.S., Jicha, B.R., Leeman, W.P., Rogers, N.W., Thirlwall, M.F., Ryan, J.G., Nicolaysen, K.E., 2007. Along-strike trace element and isotopic variation in Aleutian island arc basalt: Subduction melts sediments and dehydrates serpentine. J. Geopys. Res. 112, B06206, doi:10.1029/ 2006JB004897.

Sobolev, S.V., Babeyko, A.Y., Koulakov, I., Oncken, O., 2006. Mechanism of the Andean orogeny: insight from numerical modeling, in: Oncken, O., Chong, G., Franz, G., Giese, P., Götze, H.-J., Ramos, V.A., Strecker, M.R., Wigger, P. (Eds.), The Andes-Active Subduction Orogeny. Springer, pp. 513-535.

Tamura, Y., Tatsumi, Y., Zhao, D., Kido, Y., Shukuno, H., 2002. Hot fingers in the mantle wedge: new insights into magma genesis in subduction zones. Earth Planet. Sci. Lett. 197, 105-116.

Turner, S., Sims, K., Reagan, M., Cook, C., 2007. A ${ }^{210} \mathrm{~Pb}^{2}{ }^{226} \mathrm{Ra}_{-}{ }^{230} \mathrm{Th}^{2}{ }^{238} \mathrm{U}$ study of Klyuchevskoy and Bezymianny volcanoes, Kamchatka. Geochim. Cosmochim. Acta 71 (19), 4771-4785, 10.1016/j.gca.2007.08.006.

Wagner, D., Koulakov, I., Rabbel, W., Luehr, B.-G., Wittwer, A., Kopp, H., Bohm, M., Asch, G., 2007. Joint inversion of active and passive seismic data in Central Java. Geophys. J. Int. 170, 923-932, doi:10.1111/j.1365246X.2007.03435.

Whitehead, D., Luther, A., 1975. Dynamics of laboratory diapir and plume models. J. Geophys. Res. 80, 705-717.

Zhao, D., Tian,Y., Lei, J., Liu, L., Zheng, S., 2009. Seismic image and origin of the Changbai intraplate volcano in East Asia: Role of big mantle wedge above the stagnant Pacific slab. Phys. Earth Planet. Int. 173, 197-206.

Zhao, D., Pirajno, F., Liu, L., 2010. Mantle structure and dynamics under East Russia and adjacent regions. Russian Geology and Geophysics (Geologiya i Geofizika) 51 (9), 925-938 (1188-1203).

Editorial responsibility: A.E. Izokh 